\title{
Use of spin traps to detect superoxide production in living cells by electron paramagnetic resonance (EPR) spectroscopy
}

\author{
Kahina Abbas ${ }^{a}$, Nikola Babića, Fabienne Peyrot ${ }^{a},{ }^{,}{ }^{*}$

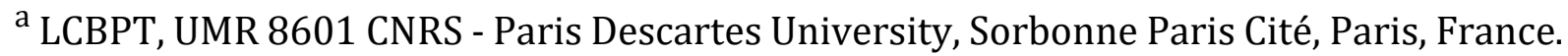 \\ ${ }^{\mathrm{b}}$ ESPE of Paris, Paris Sorbonne University, Paris, France. \\ * Corresponding author: Fabienne Peyrot \\ Laboratoire de Chimie et Biochimie Pharmacologiques et \\ Toxicologiques (UMR8601 CNRS) \\ Université Paris Descartes \\ 45 rue des Saints-Pères \\ 75006 Paris, France \\ Tel : 33 (0)1 42862175 \\ E-mail : fabienne.peyrot@parisdescartes.fr
}

\begin{abstract}
( $<250$ words)
Detection of superoxide produced by living cells has been an on-going challenge in biology for over forty years. Various methods have been proposed to address this issue, among which spin trapping with cyclic nitrones coupled to EPR spectroscopy, the gold standard for detection of radicals. This technique is based on the nucleophilic addition of superoxide to a diamagnetic cyclic nitrone, referred to as the spin trap, and the formation of a spin adduct, i.e. a persistent radical with a characteristic EPR spectrum. The first application of spin trapping to living cells dates back 1979. Since then, considerable improvements of the method have been achieved both in the structures of the spin traps, the EPR methodology, and the design of the experiments including appropriate controls. Here, we will concentrate on technical aspects of the spin trapping/EPR technique, delineating recent breakthroughs, inherent limitations and potential artifacts.
\end{abstract}

Keywords: EPR spectroscopy, ESR spectroscopy, Spin trapping, Macrophage, Free radical, Cyclic nitrone. 


\section{Abbreviations}

2-OH-E + 2-hydroxyethidium; AMPO, 5-carbamoyl-5-methyl-1-pyrroline $\mathrm{N}$-oxide; BMPO, 5-tert-butoxycarbonyl-5-methyl-1-pyrroline $N$-oxide; CD, cyclodextrin; CD-DEPMPO, 6monodeoxy-6-mono-4-[(5-diethoxyphosphoryl-5-methyl-1-pyrroline- $N$-oxide)ethylenecarbamoyl-(2,3-di-O-methyl) hexakis (2,3,6-tri- $O$-methyl)]- $\beta$-cyclodextrin; CDDIPPMPO, 6-monodeoxy-6-mono-4-[(5-diisopropoxyphosphoryl-5-methyl-1-pyrroline$N$-oxide)-ethylenecarbamoyl-(2,3-di- $O$-methyl) hexakis $\quad(2,3,6$-tri- $O$-methyl)]- $\beta$ cyclodextrin; CFU, colony-forming unit; CYPMPO, 5-(2,2-dimethyl-1,3propoxycyclophosphoryl)-5-methyl-1-pyrroline $N$-oxide; $\mathrm{CW}$, continuous wave; $\mathrm{DCFH}_{2}$, dihydro-2',7'-dichlorofluorescein; DEPMPO, 5-diethoxyphosphoryl-5-methyl-1-pyrroline $\mathrm{N}$-oxide; DFT, density functional theory; DIPPMPO, 5-diisopropoxyphosphoryl-5-methyl1-pyrroline $N$-oxide; DMPO, 5,5-dimethyl-1-pyrrolidine $N$-oxide; DMPOX, 5,5-dimethyl-2pyrrolidone- $N$-oxyl; DTPA, diethylene triamine pentaacetic acid; $\mathrm{E}^{+}$, ethidium; EMPO, 2ethoxycarbonyl-2-methyl-3,4-dihydro- $2 \mathrm{H}$-pyrrole $\mathrm{N}$-oxide; EPR, electron paramagnetic resonance (equivalent to ESR, electron spin resonance); [Fe-S] clusters, iron-sulfur clusters; fMLP, $N$-formylmethionyl-leucyl-phenylalanine; GPx, glutathione peroxidase; $\mathrm{GSH}$, glutathione; $\mathrm{H}_{2} \mathrm{O}_{2}$, hydrogen peroxide; $\mathrm{HE}$, hydroethidine; $\mathrm{HO} \cdot$, hydroxyl radical; $\mathrm{Hp}$, hemeprotein; HRP, horseradish peroxidase; Mito-DIPPMPO, $\left(4 R^{*}, 5 R^{*}\right)-5$ (diisopropyloxyphosphoryl)-5-methyl-4-[C\{[2-

(triphenylphosphonio)ethyl]carbamoyl\}oxy)methyl]pyrroline $N$-oxide bromide; PEG, polyethylene glycol; Nox, NADPH oxidase; NBT, nitro blue tetrazolium; NMR, nuclear magnetic resonance; $\mathrm{NO}^{\bullet}$, nitric oxide; $\mathrm{O}_{2}{ }^{\circ}$, superoxide radical anion; $\mathrm{ONOO}^{-}$, peroxynitrite; PBS, phosphate-buffered saline; PMA, phorbol 12-myristate 13-acetate; PMNs, polymorphonuclear leukocytes; ROS, reactive oxygen species; SCE, saturated calomel electrode; SOD, superoxide dismutase; TAMs, triarylmethyl radicals. 


\section{Contents}

1. Introduction

1.1 Superoxide as a key intermediate in oxidative stress and a mediator of cell signaling

1.2 Principle of spin trapping

1.3 Spin traps developed for cell studies

1.4 Spin adduct stability and metabolism

1.5 Comparison to other detection methods

2. Material and methods

\subsection{Spin trap stock solutions}

2.2 EPR experimental setups and sample preparation

2.2.1 Detection on cell suspensions

2.2.2 Detection on supernatant and distant analysis

2.2.3 Detection on undetached cells

2.3. Choice of acquisition parameters

3. Interpretation of the results

3.1 Identification of the spin-trapped species and of the site of radical production

3.2 Quantification

4. Troubleshooting

4.1 False positives

4.2 False negatives

5. Conclusions and perspectives 


\section{Introduction}

\subsection{Superoxide as a key intermediate in oxidative stress and a mediator of cell signaling}

Superoxide radical anion $\left(\mathrm{O}_{2}{ }^{-}\right)$is a major by-product of aerobic metabolism as a result of monoelectronic reduction of molecular oxygen by enzymes in the mitochondrial respiratory chain [1]. Other important sources, either endogenous or exogenous, include enzymes in the NADPH oxidase family (Nox), xanthine oxidase, microsomes, autoxidation reactions of reduced flavines, quinones, metal ions, metalloproteins, and exposition to ionizing radiation or photochemical irradiation. Characterized by both mild oxidizing and reducing properties, the reactivity of $\mathrm{O}_{2}{ }^{*-}$ results mainly from its interaction with radicals and cationic iron-sulfur clusters ([Fe-S] clusters). It is a precursor to more toxic species. Hydrogen peroxide $\left(\mathrm{H}_{2} \mathrm{O}_{2}\right)$ arises from spontaneous and enzyme-catalyzed disproportionation or from reduction of $\mathrm{O}_{2}{ }^{\circ}$. The highly reactive hydroxyl radical $\left(\mathrm{HO}^{\circ}\right)$ quickly follows. Peroxynitrite $\left(\mathrm{ONOO}^{-}\right)$results from the direct reaction of $\mathrm{O}_{2}{ }^{-}$with nitric oxide ( $\mathrm{NO}^{\circ}$ ). In cells, $\mathrm{O}_{2}{ }^{-}$is efficiently removed by the antioxidant enzyme superoxide dismutase (SOD) [2]. The instability of $\mathrm{O}_{2}{ }^{--}$and its poor ability to cross cell membranes due to its negative charge do not favor its role as a signaling molecule. However the SoxR transcription factor is an established example of specific $\mathrm{O}_{2}{ }^{\bullet}$ sensing through [Fe-S] clusters [3].

Monitoring production of $\mathrm{O}_{2} \cdot$ - in cells with ever increasing sensitivity is thus an important issue in biomedical research on inflammation, cancer, aging, or atherosclerosis among other fields. Several techniques have been developed to answer this question, some of which based on spectrophotometric or fluorescent probes or on HPLC detection $[4,5]$. Here we will concentrate on technical aspects of the spin trapping/EPR technique, delineating recent breakthroughs, inherent limitations and potential artifacts.

\subsection{Principle of spin trapping}

EPR spectroscopy is the most direct method for characterizing and measuring free radicals in chemistry and biology, despite its rather low sensitivity. Using conventional Xband $(\nu \simeq 9 \mathrm{GHz}$ ) spectrometers, the detection threshold is in the range of $2-3 \mu \mathrm{M}$ for a 25 $\mu \mathrm{L}$ sample (however it highly depends on the experimental setup and the acquisition parameters). Most free radicals are highly reactive and have short half-life in biological environment, and thus their concentration does not reach measurable level under such conditions. Therefore, direct observation is not possible; free radicals are observed indirectly by using spin traps. A spin trap is a diamagnetic molecule that readily reacts with a reactive radical to form a more stable radical product called a spin adduct, the concentration of which can reach measurable level (Figure 1). This radical stabilization technique is called spin trapping. Spin trapping experiments with 5,5-dimethyl-1pyrrolidine N-oxide (DMPO, Figure 1) in chemical systems were first reported in 1967 by Iwamura and Inamoto [6]. The method was further developed by Janzen and Blackburn [7], who coined the terms spin trap and spin trapping, and its first application to cellular systems dates back 1979 with detection on suspensions of stimulated human neutrophils [8].

The best spin traps for $\mathrm{O}_{2}{ }^{\bullet-}$ are compounds with a cyclic nitrone functional group that form persistent aminoxyl (nitroxide) radicals after addition of the reactive radical species. Though the spin traps are not selective of one radical, the resulting nitroxide spin adduct has a distinctive EPR spectrum which gives information about the trapped radical species. 
Indeed, both nitrogen and $\beta$-hydrogen hyperfine coupling constants in spin adducts derived from cyclic nitrones are sensitive to the nature of the trapped radical. A careful selection of the spin trap is however necessary to unequivocally distinguish oxygencentered and thiyl radical adducts [9-11]. In the following, we will append $-\mathrm{OOH}$ and $-\mathrm{OH}$ to the spin trap name to refer to the $\mathrm{O}_{2}{ }^{\bullet}$ and the $\mathrm{HO}^{\bullet}$ adducts, respectively.

\subsection{Spin traps developed for cell studies}

DMPO was the first cyclic nitrone used in spin trapping studies in cells and is still most commonly used (average of 13 articles published each year since 1990 according to Web of Science ${ }^{\mathrm{TM}}$ ), despite well identified pitfalls. Indeed, detection of DMPO-OH following incubation with stimulated neutrophils was first considered as an evidence for $\mathrm{HO}$ • production in these cells $[8,12]$, before it was proved, both experimentally and by computation, that DMPO-OOH spontaneously (non-enzymatically) decomposes to several species including DMPO-OH with a half-life under 1 min [13-15], and that stimulated neutrophils do not produce HO• [16]. Thanks to the very active research in the field of spin trap design, several derivatives of DMPO with tuned lipophilicity have been synthesized since, bearing electron-withdrawing groups at position 5 of the ring, either alkoxycarbonyl (e.g., EMPO [17], BMPO [18], AMPO [19]) or dialkoxyphosphoryl substituents (DEPMPO [20], DIPPMPO [21], CYPMPO [22]) (Figure 2). Not only do these spin traps offer a dramatically enhanced intrinsic stability of the corresponding $\mathrm{O}_{2}{ }^{\circ-}$ spin adducts in buffer, but no spontaneous decomposition to the $\mathrm{HO}^{\bullet}$ adduct is observed with these traps. The thermodynamically-preferred pathways for the spontaneous decomposition of $\mathrm{O}_{2} \cdot-$ spin adducts and the decomposition of their one-electron oxidation and reduction products were explored by computational studies, showing the need of a "loose" bond acceptor in the structure but also of both a low electron affinity and a low ionization potential for improved adduct stability [15,23,24]. Most of these traps now are commercially available and demonstrate extended shelf-life compared to DMPO, although they remain expensive and can be difficult to obtain. Phosphorylated nitrones allow easier identification of the trapped species because the large hyperfine coupling to ${ }^{31} \mathrm{P}$ is highly dependent on the structure of the trapped radical. This can however be slightly detrimental to the sensitivity of detection due to a doubling of the number of lines in the EPR spectrum, which reduces the signal-to-noise ratio. The reaction of $\mathrm{O}_{2}{ }^{\bullet-}$ with DEPMPO derivatives leads to a mixture of diastereoisomers with slightly different EPR spectra. Rapid equilibrium between conformers of the predominant trans adduct also impacts the EPR spectra [25]. Further substitution at position 4 of the pyrroline ring in a cis position compared to the dialkoxyphosphoryl group in DEPMPO or DIPPMPO simplifies the EPR spectrum by favoring the formation of one diastereoisomer and stabilizing one conformation of the ring in the adduct [26]. Moreover, conjugation of the pyrroline $\mathrm{N}$ oxide ring with a permethylated $\beta$-cyclodextrin (CD), as in CD-DEPMPO or CD-DIPPMPO $[27,28]$, allows selective detection of $\mathrm{O}_{2}{ }^{\bullet-}$ over $\mathrm{HO} 0^{*}$, probably due to competition for $\mathrm{HO} \mathrm{O}^{*}$ between the methoxy groups in the $\mathrm{CD}$ and the nitrone function. Conjugation with a CD also guaranties extracellular localization of the spin trap, by contrast with DMPO and DEPMPO which are assumed to readily permeate cell membranes [29,30]. These newly developed compounds are unfortunately not commercially available, which limits their application.

A determinant characteristic of an efficient spin trap for $\mathrm{O}_{2} 2^{-}$is the kinetic rate of the spin trapping reaction $\left(\mathrm{k}_{\mathrm{T}}\right)$. Kinetics studies of this reaction are however difficult to perform and lots of published absolute values of $\mathrm{k}_{\mathrm{T}}$ are still controversial due to biased methods of 
determination [31,32]. Comprehensive analysis of the spin trapping reaction by Villamena et al. using the density functional theory (DFT) approach greatly contributed to rationalize the design of improved spin traps $[23,33,34]$. The nucleophilic nature of $\mathrm{O}_{2}{ }^{\circ-}$ addition to nitrones explains why increasing the positive charge at position 2 of the ring through electron-withdrawing groups at C-5 is beneficial to the spin trapping rate, provided excessive steric repulsion on position 5 is avoided. Also, initial H-bond interaction of $\mathrm{O}_{2}{ }^{-}$with an $\mathrm{H}$-bond donor, such as an amide function, at position 5 further enhances its nucleophilicity towards the nitrone function, yielding higher $\mathrm{k}_{\mathrm{T}}$. Whatever the spin trap, the reaction with $\mathrm{O}_{2}{ }^{--}$remains a slow process $\left(\mathrm{kT}_{\mathrm{T}}<100 \mathrm{M}^{-1} \mathrm{~s}^{-1}\right)$ [35] and large concentrations of spin traps $(10-100 \mathrm{mM})$ are required to compete with $\mathrm{O}_{2}{ }^{*}$ spontaneous disproportionation. Fortunately, most cyclic nitrones demonstrate low toxicity towards cellular systems at these concentrations, with the exception of BMPO which was moderately toxic in CHO cells and various cancer cell lines at $50 \mathrm{mM}[29,36-$ 38].

\subsection{Spin adduct stability and metabolism}

A major limitation to the application of spin trapping with cyclic nitrones in cell studies is the instability of the spin adducts in biological systems which leads to rapid loss of EPR signal. The rate of cell-induced spin adduct decay is highly dependent on the cell type and on the activation state of the cells $[39,40]$. Modification of the flux of $\mathrm{O}_{2}{ }^{*-}$ production can also influence spin adduct stability [41], since reduction of the adducts by $\mathrm{O}_{2}{ }^{*-}$ is thermodynamically favored and supposed to play an important role in spin adduct decay [24]. Investigations, using redox agents, cells, or cellular fractions, of the biochemical mechanisms responsible for signal decay and the structure of diamagnetic products enabled to distinguish between oxidative and reductive pathways involved on this phenomenon [28,29,42-46]. Ferric hemeproteins with sufficient access to the iron cofactor, such as cytochrome P450, hemoglobin, or horseradish peroxidase (HRP), but not cytochrome $c$, could induce homolytic or heterolytic cleavage of the hydroperoxyde function in the $\mathrm{O}_{2}{ }^{-}$adducts of small-size cyclic nitrones, yielding ring-opened diamagnetic compounds or the $\mathrm{HO}^{\bullet}$ adduct, which upon further oxidation of the aminoxyl (nitroxide) function would lead to a highly unstable oxoammonium cation as an intermediate (Figure 3A) [46]. In fact, the reduction by intracellular reductants usually accounts for the largest contribution to EPR signal loss (Figure 3B). Reaction with cytosolic ascorbate forms EPR silent hydroxylamines, which are prone to fast elimination of small molecules, yielding the parent nitrone $[44,46]$. Glutathione peroxidase in the presence of glutathione (GPx/GSH) has been shown to catalyze the reduction of the $\mathrm{O}_{2}{ }^{\bullet-}$ adduct to the HO adduct [43]. Analogues of DMPO and DEPMPO displayed similar behavior when submitted to these different pathways [28]. Only when the spin trap structure ensures extracellular localization, are the adducts stabilized against cell-induced decomposition, as observed with the permethylated $\beta$-cyclodextrin conjugate CD-DIPPMPO [29].

\subsection{Comparison to other detection methods}

Detailed reviews for comparing reactive oxygen species (ROS) detection methods have been published elsewhere and are beyond the scope of this work [4,47-49]. We will thus focus only on general conclusions here to highlight differences in specificity and reliability of each method compared to spin trapping.

Among the oldest means of detection, spectrophotometric probes, i.e. substances with optical properties that change upon reaction with $\mathrm{O}_{2}{ }^{\bullet}$, are usually simpler to implement 
and are rather specific of $\mathrm{O}_{2}{ }^{-}$but they are less sensitive than spin traps [4]. Common approaches include monitoring of the reduction of cytochrome $c$ by $\mathrm{O}_{2}{ }^{\circ-}$ (increase of light absorption at $550 \mathrm{~nm}$ ) and of the reduction of various tetrazolium salts (among which nitro blue tetrazolium, NBT). Known limitations of NBT method are $\mathrm{O}_{2}{ }^{\circ-}$-independent reduction of the probe by cellular reductases and subsequent $\mathrm{O}_{2}{ }^{*-}$ production by interaction with oxygen.

Fluorescent probes, i.e. non fluorescent (or weakly fluorescent) reagents that yield fluorescent products upon reaction with ROS, such as dihydrorhodamines or the diacetate and free form of dihydro-2',7'-dichlorofluorescein ( $\mathrm{DCFH}_{2}$ ), have been most frequently used to measure oxidative stress in cells due to their good sensitivity and versatility. However they are not specific of $\mathrm{O}_{2}{ }^{*-}$ and actually have a very low reactivity with $\mathrm{O}_{2}{ }^{\bullet-}$ in absence of peroxidase-like catalyst [47]. Besides, a major artifact has been described with $2 ', 7$ '-dichlorofluorescein derivatives in that they generate ROS themselves within cells $[50,51]$. Recently, a new series of fluorescent probes, that afford a specific non-redox detection of $\mathrm{O}_{2} \cdot$ and overcome interference with cellular reductants (glutathione and $\mathrm{Fe}^{2+}$ ), has been proposed [52]. The lead compound HKSOX-1 is a trifluorosulfonate derivative of 5-carboxy-2',4',5',7'-tetrafluorofluorescein. Clearly, more work needs to be done to fully characterize these promising probes.

Less frequently used, chemiluminescent probes for $\mathrm{O}_{2} \cdot$ - based on lucigenin or luminol offer attractive high detection sensitivity. However, just as with NBT and DCFH2, redox cycling of the probes is known to generate $\mathrm{O}_{2}{ }^{--}$in cells and the detection is prone to many interferences with cellular reductants and oxidants, which are difficult to control $[4,47]$. As a consequence, there is a growing consensus against their use in living cells.

Hydroethidine (HE) and analogues are much more reactive towards $\mathrm{O}_{2}{ }^{\bullet-}$ than reduced fluoresceins and rhodamines, specifically yielding 2-hydroxyethidium $\left(2-\mathrm{OH}-\mathrm{E}^{+}\right)$. Using HPLC but not fluorescence, 2-OH- $\mathrm{E}^{+}$can unequivocally be identified and separated from ethidium $\left(\mathrm{E}^{+}\right)$and dimerization products arising from the reaction with various biologically relevant oxidants [5,53]. This is thus considered a sound qualitative method of detection. The formation of $2-0 \mathrm{H}-\mathrm{E}^{+}$is however a two-step process, the first oxidation step being non-specific, by opposition to spin trapping. The response of $\mathrm{HE}$ to $\mathrm{O}_{2}{ }^{--}$could thus be altered if another oxidant initially comes into play. Moreover, the rate of formation of $2-\mathrm{OH}-\mathrm{E}^{+}$within cells is dependent upon both $\mathrm{HE}$ cellular uptake and depletion by competing oxidation pathways. Quantitative monitoring of intracellular $\mathrm{O}_{2}{ }^{\bullet-}$ could therefore require measurement of the ratio between $2-0 \mathrm{H}-\mathrm{E}^{+}$and $\mathrm{HE}$ but this strategy needs further validation $[54,55]$.

The low sensitivity of most commonly used spin traps is a major limitation of spin trapping. More sensitive EPR probes for ROS exist, such as diamagnetic hydroxylamines which yield nitroxide compounds upon oxidation by ROS [56-58]. They are designated as spin probes and should not be confused with spin traps where a covalent bond is formed with $\mathrm{O}_{2}{ }^{\bullet}$. The rate constants of the reaction with $\mathrm{O}_{2}{ }^{\bullet-}$ are at least a hundred times higher than with cyclic nitrones [4]. However, hydroxylamines do not afford unambiguous identification of the involved ROS, since they react with $\mathrm{O}_{2}{ }^{\circ}, \mathrm{ONOO}^{-}$, peroxyl radicals, and $\mathrm{H}_{2} \mathrm{O}_{2}$ in the presence of metal ions. Use of specific scavengers can help overcoming this drawback, provided it is proved that they access the site of detection. Hydroxylamines are also sensitive to autoxidation in air, which may lead to high background signals. Their reaction products, nitroxides, are sensitive to reduction in cellular systems (mainly by ascorbate or reductases) [59], though to a lesser extent than nitrone spin adducts.

Monitoring the decay of spin probes such as triarylmethyl radicals (TAMs) is another EPR method for ROS detection. However loss of EPR signal occurs upon reaction with both $\mathrm{O}_{2}$-- 
and peroxyl radicals $[60,61]$, and even if TAMs are not sensitive to reduction by ascorbate and $\mathrm{NAD}(\mathrm{P}) \mathrm{H}$, reduction by reductases is quite efficient and can interfere with the detection.

In the end, it seems that the ideal, flawless detection method for $\mathrm{O}_{2}{ }^{\bullet-}$ within cells is still out of reach. Yet, combination of well-characterized methods can help develop a more indepth analysis of ROS produced in cellular systems, spin trapping with cyclic nitrones coupled to EPR being one of them.

\section{Material and methods}

\subsection{Spin trap stock solutions}

It is essential that spin trap solutions are free of contamination by hydroxylamine and nitroxide impurities that can impair $\mathrm{O}_{2} \cdot$ detection and give artifacts. Contaminating hydroxylamines can be tested by treatment with ferricyanide which converts them to EPR-visible nitroxides [62]. Most commercially available DMPO contains paramagnetic impurities. More recently described spin traps are usually more stable upon long-term storage at $-20^{\circ} \mathrm{C}$ or lower. However, DEPMPO and EMPO are colorless to slightly yellow oils that can also be contaminated. Distillation of the neat oils is difficult on a small scale. Purification methods of contaminated solutions of spin traps by sequential treatment by activated charcoal and ferricyanide have been proposed but can be rather tedious [31,6366]. By contrast, BMPO and CYPMPO are crystalline solids and are easily purified by recrystallization $[18,22]$.

Stock solutions of spin traps should be prepared in an appropriate buffered saline containing a metal chelator such as diethylene triamine pentaacetic acid (DTPA, 0.1 - 1 $\mathrm{mM}$ ) when metal ions are not required in the assay and should be stored at $-20^{\circ} \mathrm{C}$ or below. A sufficient amount of the spin trap should be introduced in the assay before the start of $\mathrm{O}_{2}$ - production to ensure satisfactory accumulation of the spin adduct above EPR detection limit. Enhancement of spin adduct decay by excessive amounts of spin trap has been described [32], however in the presence of cells this effect might be masked by cellinduced rapid spin adduct decay. Typical final concentrations used in the literature are $100 \mathrm{mM}$ for DMPO, $50 \mathrm{mM}$ for BMPO, and 5-20 mM for DEPMPO and CYPMPO.

Use of phenol red- and serum-containing culture media in spin trapping experiments should be avoided since they contain many components susceptible to generate or scavenge free radicals or to reduce spin adducts $[67,68]$. If these are used for the culture, cells should be carefully washed with buffered saline before addition of the spin trap.

\subsection{EPR experimental setups and sample preparation}

In this section, we will only describe experimental setups requiring commercial X-band continuous wave (CW) spectrometers and resonators.

\subsubsection{Detection on cell suspensions}

Most spin trapping experiments in the literature have been performed on cell suspensions using either quartz flat cells or glass capillaries as sample holders. Phagocytic cells represent the most studied cell type with DMPO [8,12,16,69-72], because high level of $\mathrm{O}_{2}{ }^{--}$production can be conveniently triggered by incubation with various stimulants. Besides, results have been obtained on menadione-treated endothelial cells or enterocytes $[43,73]$, endothelial cells exposed to anoxia-reoxygenation cycles $[74,75]$, or 
N. gonorrhoeae bacteria upon incubation with paraquat [76]. More recent spin traps were also individually tested in the same phagocytic cell systems [36,39,44,57]. The quartz flat cell is however a rather insensitive technique, poorly suited to low radical production (especially basal conditions), and requires large amounts of spin trap and cells. Artifacts due to cross-contamination between runs can occur if thorough cleaning of adherent proteins is not performed after analysis of each individual sample. More importantly, in such closed systems, oxygen supply is limited and hypoxia can impair detection of $\mathrm{O}_{2}{ }^{\circ-}$, either because the production of oxygen-derived radicals themselves is lowered or because reductases become activated under these conditions enhancing spin adduct decay - a process that has been investigated using sterically-shielded nitroxides $[77,78]$. Use of a disposable length of gas-permeable PTFE tubing (Extruded Sub-Lite-Wall, inside diameter $0.635 \mathrm{~mm}$, wall thickness $0.051 \mathrm{~mm}$; Zeus Industrial Products Ltd., Ireland) folded twice in a W shape and inserted in a 4-mm EPR quartz tube solves many of these problems. The small sample size $(100 \mu \mathrm{L})$ allows analysis of multiple conditions from the same stock of cells, comparison of spin trap efficiency of detection, and avoids artifacts of contamination.

Shi et al. determined the optimal conditions for detection of $\mathrm{O}_{2}{ }^{\bullet-}$ produced in human mammary epithelial cells, MCA-10A, upon treatment with a polycyclic aromatic hydrocarbon, 1,6-benzo[a]pyrene quinone $(20 \mu \mathrm{M})$ in phenol red- and serum-free cell growth medium containing $0.1 \mathrm{mM}$ DTPA [40]. Only the HO• spin adducts derived from reduction of the $\mathrm{O}_{2} \cdot$ adducts in cells were detected in this case, as evidenced by inhibition with SOD. In this cellular system, the signal intensity was maximum using $2.5 \times 10^{6}$ cells/mL, $50 \mathrm{mM}$ spin trap, normoxia conditions, and physiological temperature of $37^{\circ} \mathrm{C}$. From the comparison of four spin traps (one of which did not give any signal), the authors concluded that the maximal intensities (measured as low-field peak height of EPR spectra) obtained with DMPO, BMPO, and DEPMPO were similar, but that detection was more transient with DMPO. The maximum intensity was reached later and lasted longer with DEPMPO.

In a study using suspensions of RAW 264.7 macrophages $\left(3.6 \times 10^{6}\right.$ cells/ $\left.100 \mu \mathrm{L}\right)$ in phosphate-buffered saline (PBS), we compared the spin trapping efficiencies of six spin traps (DMPO, BMPO, DEPMPO, DIPPMPO, Mito-DIPPMPO, and CD-DIPPMPO) at 5-10 mM final concentration and $21^{\circ} \mathrm{C}$ upon stimulation with phorbol 12-myristate 13-acetate (PMA, $5 \mu \mathrm{M}, 20 \mathrm{~min}$ ) [29] (Figure 4). Optimal detection was not obtained at such low concentrations with DMPO and BMPO, while $50 \mathrm{mM}$ afforded satisfactory signal with both spin traps. Besides, with this cellular system, mixtures of $\mathrm{O}_{2}{ }^{\bullet-}$ and $\mathrm{HO}$ adducts were observed. The SOD-inhibitable signal of the HO• adduct was preponderant with DMPO, BMPO, DEPMPO, and DIPPMPO, while Mito-DIPPMPO and CD-DIPPMPO enabled a greater detection of the $\mathrm{O}_{2} \cdot$ adduct, with a low (if any) amount of $\mathrm{HO}^{\bullet}$ adduct in the case of CDDIPPMPO (Figure 5). The sensitivity of detection was dramatically increased with CDDIPPMPO compared to all other spin traps, making detection on unstimulated macrophages possible for the first time. The superiority of CD-DIPPMPO over other spin traps used was attributed to its extracellular localization which protects the spin adducts from intracellular reductants. It appears that the larger linewidth of CD-DIPPMPO-OOH, arising from a higher molecular tumbling correlation time, which could have reduced the signal-to-noise ratio compared to DEPMPO-OOH, is largely outbalanced by the increase in adduct stability.

These last two examples show how dependent on the cell type the detection is, which means that optimal experimental conditions can vary from one study to another. 
Results obtained on cell suspensions may occasionally differ from physiological responses. Cell harvesting methods, such as scraping or trypsinization, can undermine cell integrity. Physical damage to cells induced by mechanical detachment may reduce viability [79,80] or alter cell metabolism [81], while partial enzymatic digestion of membrane-expressed proteins may impair cell function [82-86]. Therefore different alternative setups have been proposed to perform detection of $\mathrm{O}_{2} \cdot-$ produced by adherent cells. In the next sections, we will review detection on the supernatant and detection directly performed on adherent cells.

\subsubsection{Detection on supernatant and distant analysis}

When adherent cells are incubated with spin traps, the spin adduct formed by trapping of extracellular $\mathrm{O}_{2}{ }^{\bullet-}$ accumulates in the supernatant and can be detected by EPR, though this method has been used in few studies. Optimal incubation times and spin trap concentration depend both on the level of $\mathrm{O}_{2} \cdot$ - production, on the spin trapping rate, and on the stability of the adduct in the presence of cells.

Endothelium-derived $\mathrm{O}_{2}{ }^{\circ}$, a key player in atherosclerosis and vascular aging, is particularly difficult to measure because of its low level of production. Pre-confluent and post-confluent cultured bovine aortic endothelial cells $\left(1.5-2.5 \times 10^{6}\right.$ cells $)$ in $25 \mathrm{~cm}^{2}$ flasks were incubated with DMPO $(150 \mathrm{mM}$ in a mix containing $1 \mathrm{~g} / \mathrm{L}$ glucose, $0.2 \mathrm{~g} / \mathrm{L}$ $\mathrm{CaCl}_{2}, 0.0059 \mathrm{~g} / \mathrm{L}$ DTPA, $0.15 \mathrm{~g} / \mathrm{L} \mathrm{NaCl}, 0.37 \mathrm{~g} / \mathrm{L} \mathrm{KCl}$ in sodium phosphate buffer at $\mathrm{pH}$ 7.4) for $15 \mathrm{~min}$. The supernatant transferred to a quartz cell was used to assess production of $\mathrm{O}_{2} \cdot$ under stimulation by the calcium ionophore $\mathrm{A} 23187$ in a dosedependent manner (3-10 $\mu \mathrm{M})$ in PBS [65]. The signal, identified as resulting from the DMPO-OH adduct, was completely inhibited by SOD $(30 \mathrm{U} / \mathrm{mL})$, whereas it was unaltered by addition of catalase $(2000 \mathrm{U} / \mathrm{mL})$, confirming it originated from the trapping of extracellular $\mathrm{O}_{2}{ }^{\circ}$. Production by unstimulated cells was barely detectable under these conditions.

Use of a spin trap that leads to more stable spin adducts, such as BMPO, allows distant analysis of the supernatant after freezing in liquid nitrogen when an EPR spectrometer is not available at the site of experiment [87]. Dysfunctional porcine aortic endothelial cells obtained by successive passages were thus shown to produce significantly more $\mathrm{O}_{2}{ }^{*-}$ than functional cells using this method [88]. There, one-hour incubation of the cells in the presence of $50 \mathrm{mM} \mathrm{BMPO}$ in phosphate buffer under agitation at $37^{\circ} \mathrm{C}$, with or without addition of SOD $(300 \mathrm{U} / \mathrm{mL})$, was performed and the supernatant was rapidly frozen in liquid nitrogen. The samples were allowed to thaw just before analysis and were rapidly transferred to a 4-bore AquaX ${ }^{\circledR}$ (Bruker, Wissembourg). This specific sample cell, compatible with most standard EPR cavities, is made of closely spaced quartz capillaries with fittings that make it easy to fill and rinse with a syringe while installed within the spectrometer. Series of samples can be analyzed in a short period of time using this system. Adherent proteins can be removed by flushing the system with sodium hydroxide solution followed by buffer between runs since the cell is chemically-resistant.

Detection on the supernatant with BMPO was also successfully applied to the detection of $\mathrm{O}_{2}{ }^{--}$produced extracellularly by Nox family enzymes overexpressed at the plasma membrane of human embryonic kidney HEK 293 cells (Figure 6). NADPH oxidase 5 (Nox5) and dual oxidase 2 (Duox2) are large homologues sharing a plasma membrane associated flavoprotein and an $\mathrm{N}$-terminal extension comprising four and two EF-hand motifs, respectively, implicated in their $\mathrm{Ca}^{2+}$ activation. Duox2 has an additional transmembrane helix and a peroxidase homology ectodomain with several glycosylated 
sites. While Nox5 and immature Duox 2 catalyze the production of $\mathrm{O}_{2}{ }^{--}$[89], mature Duox2 is involved in thyroid hormones biosynthesis as the $\mathrm{H}_{2} \mathrm{O}_{2}$ generator associated with thyroperoxidase. Mutations in Duox2 produce congenital hypothyroidism in humans. SOD-inhibitable and $\mathrm{Ca}^{2+}$-dependent accumulation of $\mathrm{BMPO}-\mathrm{OH}$ in the supernatant following release of $\mathrm{O}_{2} \cdot$ - by Nox 5 but not by mature Duox 2 at the plasmic membrane was observed (Figure 7). Besides, it confirmed the selectivity of detection of $\mathrm{O}_{2}{ }^{\bullet-}$ versus $\mathrm{H}_{2} \mathrm{O}_{2}$ with BMPO since extracellular $\mathrm{H}_{2} \mathrm{O}_{2}$ productions by both cell lines in the presence of ionomycin were similar (as assayed by the increase in homovanilic acid fluorescence in the presence of HRP). On the contrary, BMPO did not allow detection of $\mathrm{O}_{2}{ }^{\bullet-}$ produced by immature Duox2 at the endoplasmic reticulum in cell lines lacking the human Duox2 maturation factor hDuoxA2 (i.e. in HEK-hDuox2/pcDNA5FRT cells).

Damage to the cell layer and presence of cells in the supernatant upon freezing should be avoided because leakage of intracellular components will reduce the stability of the spin adducts in the sample, a problem which can be identified when fast signal decay occurs during EPR acquisition. Despite its simple implementation, a significant drawback of the detection on supernatant is the large volume of solution used to cover the cell layer in culture wells and the consequent large amount of spin trap required for the experiments.

\subsubsection{Detection on undetached cells}

As an alternative to detection on the supernatant, measurement can be performed directly on adherent cells introduced inside the EPR cavity by different tricks.

Reinke et al. allowed polymorphonuclear leukocytes (PMNs) to adhere to the walls of a quartz flat EPR cell which was placed horizontally for 3 min before recording [90]. They could monitor a large and long-lasting $N$-formylmethionyl-leucyl-phenylalanine (fMLP)induced $\mathrm{O}_{2}{ }^{*}$ release by adherent PMNs using DMPO, while no signal was detected when spin trapping was performed on PMNs in suspension. Unlike fMLP-, PMA-induced $\mathrm{O}_{2}{ }^{\circ-}$ release by PMNs was not influenced by cell adhesion.

Britigan et al. performed spin trapping of $\mathrm{O}_{2}{ }^{*-}$ with DMPO $(100 \mathrm{mM})$, in Hank's balanced salt solution without phenol red and containing $0.1 \mathrm{mM}$ DTPA, using endothelial cells cultured on microcarrier beads (Cytodex 3, Pharmacia, Piscataway, NJ) [91]. The final cell concentration in the quartz flat EPR cell with 25 vol\% microcarrier beads reached 0.5 $1 \times 10^{7}$ cells $/ \mathrm{mL}$. Upon exposure to paraquat $(1 \mathrm{mM})$, DMPO-OH signal was observed. It was inhibited by SOD $(30 \mathrm{U} / \mathrm{mL})$, while it remained unchanged in the presence of catalase $(400 \mathrm{U} / \mathrm{mL})$ or DMSO, which is consistent with $\mathrm{O}_{2} \bullet$ trapping.

However, the problems of oxygen supply inside flat quartz cells and of potential crosscontamination between runs already mentioned in previous sections remain with these techniques. To overcome these issues, we recently proposed to perform detection on cells attached to coverslip glasses initially designed for microscope studies [92]. RAW 264.7 macrophages were incubated for 20 min with four spin traps (DEPMPO, DIPPMPO, MitoDIPPMPO, or CD-DIPPMPO, 5-10 mM) and PBS containing DTPA (1 mM) in 24-well culture plates $(150 \mu \mathrm{L} /$ well). Two coverslips were then mounted (cell layer facing outwards) on a quartz slide using EPR silent silicon vacuum grease (Bluestar silicones, Caronno Pertusella, Italy) and introduced inside the EPR TM cavity equipped with a flat quartz protection sleeve (Figure 8). All spin traps gave satisfactory detection upon macrophage stimulation with PMA and the results correlated those obtained with cell suspensions. Again, only the $\mathrm{O}_{2}{ }^{-}$adduct was observed with CD-DIPPMPO. This setup requires a reduced number of cells for one condition (500 000 cells on two coverslips) and a limited 
amount of spin trap. Moreover, sample preparation is straightforward which allows medium-throughput EPR detection of $\mathrm{O}_{2}{ }^{\bullet-}$ production on adherent cells.

\subsection{Choice of acquisition parameters}

As mentioned in previous examples, the choice of EPR parameters for the experiments can be critical because the spin adducts usually form at low and transient concentrations. It is good practice to pretune the cavity with some control sample (buffer or untreated cells) in order to save time when analyzing samples containing short-lived spin adducts. Microwave power between 10 and $20 \mathrm{~mW}$ is widely accepted as optimal value to obtain the maximal EPR intensity while avoiding saturation of the signal. However undesired heating of the sample can occur even at $20 \mathrm{~mW}$, which can influence both cell metabolism, spin trapping rate, and spin adduct decay [35]. It is therefore important to keep this value constant and to be aware that results cannot be compared when different EPR sample cells are used (glass capillaries, flat cells, AquaX, gas-permeable tubing...).

Modulation of the magnetic field is used in conventional EPR spectrometers in order to enhance the sensitivity, which results in the EPR spectrum being recorded as the first derivative of the absorption signal with respect to magnetic field. Recommended modulation amplitude is generally around $0.1 \mathrm{mT}$ for nitroxides. However it can be increased up to $0.25 \mathrm{mT}$ in order to fathom very weak signals of spin adducts from the baseline, with only negligible distortion of the EPR spectra.

When looking at very weak signals, EPR spectroscopists usually increase signal-to-noise ratio by using large time constants to filter noise or by repeatedly acquiring the spectrum and subsequently adding each spectrum together. As a result, the signal increases proportionally with the number of scans $N$, random noise with $\sqrt{N}$, and thus signal-tonoise ratio with $\sqrt{N}$. However, modern spectrometers also allow recording of large series of spectra as a function of time and this function can be used as an advantage to further increase the sensitivity of detection with spin traps. By keeping the time constant low and recording large series of spectra that are then treated with statistical data analysis methods such as singular value decomposition (SVD), one can extract kinetic information in addition to performing noise filtration [31,32]. We used this method to unravel unstimulated $\mathrm{O}_{2}$-- production in RAW 264.7 macrophage suspensions with CD-DIPPMPO [29].

\section{Interpretation of the results}

\subsection{Identification of the spin-trapped species and of the site of radical production}

According to the theory of spin trapping, the trapped radical can easily be identified by the characteristic EPR spectrum of the spin adduct. Hyperfine coupling constants of $\mathrm{O}_{2}{ }^{\circ-}$ and $\mathrm{HO}^{\bullet}$ adducts of common spin traps have been tabulated $[9,28]$. In the case of phosphorylated spin traps, significant lines for $\mathrm{O}_{2}{ }^{\bullet-}$ and $\mathrm{HO} \cdot$ adducts do not overlap, which makes interpretation more straightforward. Computer-assisted simulation of the EPR spectra with different softwares (such as WinSim, Roki, or Easyspin) helps in the determination of the relative proportions of overlapping species [93-95].

Interpretation of spin trapping results can sometimes be difficult due to the instability of the spin adducts in biological systems and the conversion of $\mathrm{O}_{2}{ }^{\bullet-}$ to $\mathrm{HO}$-adduct (see section 1.4). However, relatively straightforward procedures exist to determine whether $\mathrm{O}_{2}{ }^{\circ-}$ or $\mathrm{HO}^{\bullet}$ radicals have been trapped [96]. Most importantly, to prove extracellular $\mathrm{O}_{2}{ }^{\bullet-}$ 
radical formation, incubation with SOD or polyethylene glycol-conjugated SOD (SOD-PEG) $(30 \mathrm{U} / \mathrm{mL})$ should prevent the formation of the $0_{2} 2^{\bullet-}$ adduct, while catalase $(200 \mathrm{U} / \mathrm{mL})$ should have no effect. (Heat-inactivated SOD can be used to rule out interference of preservatives in commercial preparations of the enzymes.) Neither SOD nor SOD-PEG can cross the cell membrane at short incubation times and thus these controls cannot be used to track down intracellular production of $\mathrm{O}_{2}{ }^{\circ}$.

The origin of $\mathrm{HO}^{\bullet}$ adduct can be identified by further controls (Figure 9). In the circumstances of $\mathrm{HO}^{\bullet}$ formation, addition of small amounts ( $1 \mathrm{vol} \%$ ) of ethanol or DMSO will lead to an inhibition of the HO• adduct and will result in appearance of a new species due to the trapping of secondary $\alpha$-hydroxyethyl or methyl radicals, respectively. HO• adduct resistant to both SOD- and ethanol/DMSO-inhibition likely originates from the reduction of $\mathrm{O}_{2} \cdot$ adduct by intracellular components and can thus be regarded as a sign of intracellular $\mathrm{O}_{2}{ }^{-}$production, provided nucleophilic addition of water under the experimental conditions has been excluded (see section 4.1).

Besides, intracellular versus extracellular localization of spin adducts can be probed by using membrane-impermeant paramagnetic salts, such as tri(oxalato) chromiate(III) (30 $\mathrm{mM}$ ) [97] or tris(ethylenediamine)nickel(II) chloride (100 mM) [29]. Concentration- and distance-dependent magnetic relaxation enhancement mechanisms (Heisenberg exchange) between the paramagnetic metal ions and the organic radicals lead to linebroadening and diminution of intensity of the EPR signal of spin adducts present in the extracellular space, while intracellular species are unaffected. Passive diffusion of the spin adducts away from their sites of production is however a possibility that must be taken into account for long-lived adducts.

\subsection{Quantification}

The EPR spectrum, being the first derivative of the absorption signal, contains information about the number of spins in the sample. Assuming the recording parameters have been properly chosen to avoid saturation of the signal, the intensity of the EPR spectrum - defined as the area under the absorption curve - is proportional to the number of spins and the concentration of the spin adduct easily follows from the comparison with an external standard of known concentration (usually a stable nitroxide). Can this quantity be used to derive a quantitative estimation of $\mathrm{O}_{2} \cdot$ production from cells? Roubaud et al. suggested that DEPMPO has ideal properties for such quantitative measurements [39]. Considering the poor spin trapping rate and the low spin adduct stability in the presence of biological systems, any attempt to quantify $\mathrm{O}_{2}{ }^{\bullet-}$ production by cells using spin trapping is however extremely difficult and should be considered with caution, especially when the concentration of oxygen varies during the experiment, altering both the $\mathrm{O}_{2}{ }^{\bullet-}$ production rate and the reducing potency of cells. In our opinion, only CD-DIPPMPO, with its high intrinsic adduct stability and its extracellular localization that prevents cell-induced decay, when used in combination with gas-permeable tubing, would make quantitative estimates more reliable.

\section{Troubleshooting}

\subsection{False positives}

Nitrones are very reactive organic compounds and various reactions that do not involve radical trapping may lead to nitroxides and undesired EPR signals. Specific warnings against misinterpretations appeared in the literature $[96,98]$. Possible artifacts include: i) 
oxidation of DMPO and related nitrones to the corresponding hydroxamic acid by metal ions or other oxidizing systems, followed by oxidation to a nitroxide characterized by a 7line EPR spectrum [99]; ii) inverted spin trapping [100,101], and iii) the ForresterHepburn mechanism [102] (Figure 10). These last two mechanisms lead to radicals that are identical to spin adducts but through combinations of mono-electronic oxidation of the spin trap and nucleophilic addition, in either order. Inverted spin trapping, where the oxidation precedes the nucleophilic addition, is a rather limited source of artifacts with cyclic nitrones in biological systems since their oxidation potentials are very high

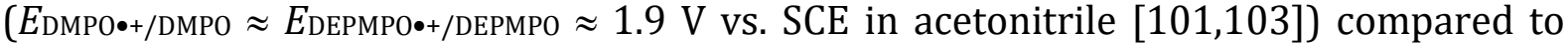
biologically-relevant oxidation potentials, but it should be considered in the presence of high valency metal ions $\left(\mathrm{Fe}^{3+}, \mathrm{Cu}^{2+}, \mathrm{Mn}^{4+}\right)$. These species can oxidize the nitrone to the radical cation and make it susceptible to hydration to form the $\mathrm{HO}^{\bullet}$ adduct (water being the most abundant nucleophile in biological systems). The Forrester-Hepburn mechanism, where the first step involves nucleophilic attack of the $\beta$-carbon of the nitrone by nucleophiles such as water, sulfite, or thiols and formation of a readily-oxidizable hydroxylamine product, is potentially a greater source of artifacts, especially with nitrones bearing a higher positive charge than DMPO on this position like in DEPMPO, and in the presence of trace metal ions that further activate the electrophilic character of the nitrone function by complexation $[104,105]$. Nucleophilic addition of water leading to the HO adduct is the main concern in the absence of metal chelators. Timmins et al. proposed a technique involving pre-incubation with isotopically labeled spin traps to identify such artifacts [106]. This was further refined by Leinisch et al. [62,107] and completed by auxiliary experiments by Ranguelova et al. [98].

\subsection{False negatives}

Unsuccessful EPR detection using spin traps should not be considered as a proof of absence of radical production by the cellular system. The actual spin trap concentration at the site of $\mathrm{O}_{2} \cdot$ production inside cells may be limiting if the rate of cell membrane crossing by DMPO and DEPMPO is slow [30]. The low spin trapping rate and fast cellinduced decay of spin adducts can prevent accumulation of the spin adduct above the detection limit of EPR when low fluxes of $\mathrm{O}_{2}{ }^{\bullet-}$ are produced. Incubation with preformed adducts or stable nitroxides can be used to probe the metabolic potential of the cells and test this hypothesis [29]. Simultaneous production of NO may also prevent trapping of $\mathrm{O}_{2}{ }^{--}$with cyclic nitrone spin traps [108].

\section{Conclusions and perspectives}

Since the first application of the technique of spin trapping in cellular systems in the 1970s, many improvements were achieved regarding the structures and properties of the spin traps designed for $\mathrm{O}_{2}{ }^{-}$- detection. The specificity of detection remains the greatest strength of this methodology, together with the absence of redox cycling of the probes within cells. Nowadays extracellular detection of $\mathrm{O}_{2}{ }^{--}$production can be performed with excellent sensitivity using standard spectrometers and CD-DIPPMPO, however commercial unavailability of the new-generation spin traps is a serious brake to further spreading. On the other hand, low sensitivity for the detection of intracellular $\mathrm{O}_{2}{ }^{--}$ production is still a major shortcoming of the technique, which has up-to-now prevented detection of mitochondrial $\mathrm{O}_{2}{ }^{\bullet-}$ within cells for example, despite progresses in CW EPR spectrometer sensitivity and in chemical design of cyclic nitrone spin traps. Future 
breakthroughs will certainly come from the use of new detection methodologies such as rapid-scan EPR [109]. In rapid-scan EPR, a dramatic increase in sensitivity (> 40 times compared to CW EPR) is obtained by scanning the magnetic field through resonance at a rate that is high compared to electron spin relaxation rates. With this method, $0.5 \mu \mathrm{M}$ of BMPO-OOH was detected in suspensions of Enterococcus faecalis with $2 \times 10^{6} \mathrm{CFU} / \mathrm{mL}$ at a rate of $\mathrm{O}_{2} \cdot$ production of $0.2 \mu \mathrm{M} / \mathrm{min}$ [110], and imaging of spin trapped radicals at low and physiologically-useful concentrations has become possible [111].

\section{Acknowledgments}

The results in Figures 6 and 7 were obtained through a collaboration between F. Peyrot, R. Ameziane-El-Hassani, Y.-M. Frapart, J.-L. Boucher, D. Mansuy, M. El Mzibri, A. Virion, and C. Dupuy, and were presented as a poster during SFRR Europe 2007 meeting in Vilamoura, Portugal. HEK-hNox5 cells used in this study were kindly provided by Dr K. H. Krause, Biology of Aging Laboratories, University of Geneva, Switzerland.

\section{References}

[1] B. D’Autréaux, M.B. Toledano, ROS as signalling molecules: mechanisms that generate specificity in ROS homeostasis, Nat. Rev. Mol. Cell Biol. 8 (2007) 813-824. doi:10.1038/nrm2256.

[2] J.M. McCord, I. Fridovich, Superoxide Dismutase: an enzymic function for erythrocuprein (hemocuprein), J. Biol. Chem. 244 (1969) 6049-6055.

[3] E. Hidalgo, B. Demple, An iron-sulfur center essential for transcriptional activation by the redox-sensing SoxR protein, EMBO J. 13 (1994) 138-146.

[4] G. Bartosz, Use of spectroscopic probes for detection of reactive oxygen species, Clin. Chim. Acta Int. J. Clin. Chem. 368 (2006) 53-76. doi:10.1016/j.cca.2005.12.039.

[5] J. Zielonka, S. Srinivasan, M. Hardy, O. Ouari, M. Lopez, J. Vasquez-Vivar, N.G. Avadhani, B. Kalyanaraman, Cytochrome c-mediated oxidation of hydroethidine and mito-hydroethidine in mitochondria: identification of homo- and heterodimers, Free Radic. Biol. Med. 44 (2008) 835-846. doi:10.1016/j.freeradbiomed.2007.11.013.

[6] M. Iwamura, N. Inamoto, Novel formation of nitroxide radicals by radical addition to nitrones, Bull. Chem. Soc. Jpn. 40 (1967) 703. doi:10.1246/bcsj.40.703.

[7] E.G. Janzen, B.J. Blackburn, Detection and identification of short-lived free radicals by an electron spin resonance trapping technique, J. Am. Chem. Soc. 90 (1968) 5909-5910. doi:10.1021/ja01023a051.

[8] M.R. Green, H.A. Hill, M.J. Okolow-Zubkowska, A.W. Segal, The production of hydroxyl and superoxide radicals by stimulated human neutrophils measurements by EPR spectroscopy, FEBS Lett. 100 (1979) 23-26.

[9] G.R. Buettner, Spin trapping: ESR parameters of spin adducts, Free Radic. Biol. Med. 3 (1987) 259-303. doi:10.1016/S0891-5849(87)80033-3.

[10] H. Karoui, N. Hogg, C. Fréjaville, P. Tordo, B. Kalyanaraman, Characterization of sulfur-centered radical intermediates formed during the oxidation of thiols and sulfite by peroxynitrite. ESR-spin trapping and oxygen uptake studies, J. Biol. Chem. 271 (1996) 6000-6009. doi:10.1074/jbc.271.11.6000. 
[11] H. Karoui, F. Chalier, J.-P. Finet, P. Tordo, DEPMPO: an efficient tool for the coupled ESR-spin trapping of alkylperoxyl radicals in water, Org. Biomol. Chem. 9 (2011) 2473-2480. doi:10.1039/c0ob00876a.

[12] H. Rosen, S.J. Klebanoff, Hydroxyl radical generation by polymorphonuclear leukocytes measured by electron spin resonance spectroscopy, J. Clin. Invest. 64 (1979) 1725-1729. doi:10.1172/JCI109637.

[13] E. Finkelstein, G.M. Rosen, E.J. Rauckman, Production of hydroxyl radical by decomposition of superoxide spin-trapped adducts, Mol. Pharmacol. 21 (1982) 262-265.

[14] E.J. Locigno, J.L. Zweier, F.A. Villamena, Nitric oxide release from the unimolecular decomposition of the superoxide radical anion adduct of cyclic nitrones in aqueous medium, Org. Biomol. Chem. 3 (2005) 3220-3227. doi:10.1039/b507530k.

[15] F.A. Villamena, J.K. Merle, C.M. Hadad, J.L. Zweier, Superoxide radical anion adduct of 5,5-dimethyl-1-pyrroline N-oxide (DMPO). 2. The thermodynamics of decay and EPR spectral properties, J. Phys. Chem. A. 109 (2005) 6089-6098. doi:10.1021/jp0524330.

[16] B. Britigan, G. Rosen, Y. Chai, M. Cohen, Do human neutrophils make hydroxyl radical - Determination of free radicals generated by human neutrophils activated with a soluble or particulate stimulus using electron paramagnetic resonance spectrometry, J. Biol. Chem. 261 (1986) 4426-4431.

[17] G. Olive, A. Mercier, F. Le Moigne, A. Rockenbauer, P. Tordo, 2-Ethoxycarbonyl-2methyl-3,4-dihydro-2H-pyrrole-1-oxide: evaluation of the spin trapping properties, Free Radic. Biol. Med. 28 (2000) 403-408. doi:10.1016/S08915849(99)00254-3.

[18] H.T. Zhao, J. Joseph, H. Zhang, H. Karoui, B. Kalyanaraman, Synthesis and biochemical applications of a solid cyclic nitrone spin trap: A relatively superior trap for detecting superoxide anions and glutathiyl radicals, Free Radic. Biol. Med. 31 (2001) 599-606. doi:10.1016/S0891-5849(01)00619-0.

[19] F.A. Villamena, A. Rockenbauer, J. Gallucci, M. Velayutham, C.M. Hadad, J.L. Zweier, Spin trapping by 5-carbamoyl-5-methyl-1-pyrroline N-oxide (AMP0): Theoretical and experimental studies, J. Org. Chem. 69 (2004) 7994-8004. doi:10.1021/jo049244i.

[20] C. Frejaville, H. Karoui, B. Tuccio, F. Lemoigne, M. Culcasi, S. Pietri, R. Lauricella, P. Tordo, 5-Diethoxyphosphoryl-5-methyl-1-pyrroline N-oxide (DEPMPO) - a new phosphorylated nitrone for the efficient in-vitro and in-vivo spin-trapping of oxygen-centered radicals, J. Chem. Soc.-Chem. Commun. (1994) 1793-1794. doi:10.1039/c39940001793.

[21] F. Chalier, P. Tordo, 5-Diisopropoxyphosphoryl-5-methyl-1-pyrroline N-oxide, DIPPMPO, a crystalline analog of the nitrone DEPMPO: synthesis and spin trapping properties, J. Chem. Soc.-Perkin Trans. 2. (2002) 2110-2117. doi:10.1039/b206909c.

[22] M. Kamibayashi, S. Oowada, H. Kameda, T. Okada, O. Inanami, S. Ohta, T. Ozawa, K. Makino, Y. Kotake, Synthesis and characterization of a practically better DEPMPOtype spin trap, 5-(2,2-dimethyl-1,3-propoxy cyclophosphoryl)-5-methyl-1pyrroline N-oxide (CYPMPO), Free Radic. Res. 40 (2006) 1166-1172. doi:10.1080/10715760600883254.

[23] Y. Han, B. Tuccio, R. Lauricella, A. Rockenbauer, J.L. Zweier, F.A. Villamena, 
Synthesis and spin-trapping properties of a new spirolactonyl nitrone, J. Org. Chem. 73 (2008) 2533-2541. doi:10.1021/jo702434u.

[24] F.A. Villamena, Superoxide radical anion adduct of 5,5-dimethyl-1-pyrroline Noxide. 6. Redox properties, J. Phys. Chem. A. 114 (2010) 1153-1160. doi:10.1021/jp909614u.

[25] C. Frejaville, H. Karoui, B. Tuccio, F. Lemoigne, M. Culcasi, S. Pietri, R. Lauricella, P. Tordo, 5-(Diethoxyphosphoryl)-5-methyl-1-pyrroline $\mathrm{N}$-oxide: a new efficient phosphorylated nitrone for the in vitro and in vivo spin trapping of oxygencentered radicals, J. Med. Chem. 38 (1995) 258-265. doi:10.1021/jm00002a007.

[26] M. Hardy, F. Chalier, O. Ouari, J.-P. Finet, A. Rockenbauer, B. Kalyanaraman, P. Tordo, Mito-DEPMPO synthesized from a novel NH2-reactive DEPMPO spin trap: a new and improved trap for the detection of superoxide, Chem. Commun. (2007) 1083-1085. doi:10.1039/b616076j.

[27] M. Hardy, D. Bardelang, H. Karoui, A. Rockenbauer, J.-P. Finet, L. Jicsinszky, R. Rosas, O. Ouari, P. Tordo, Improving the trapping of superoxide radical with a betacyclodextrin-5-diethoxyphosphoryl-5-methyl-1-pyrroline-N-oxide (DEPMPO) conjugate, Chem.- Eur. J. 15 (2009) 11114-11118. doi:10.1002/chem.200901342.

[28] N. Bézière, M. Hardy, F. Poulhès, H. Karoui, P. Tordo, O. Ouari, Y.-M. Frapart, A. Rockenbauer, J.-L. Boucher, D. Mansuy, F. Peyrot, Metabolic stability of superoxide adducts derived from newly developed cyclic nitrone spin traps, Free Radic. Biol. Med. 67 (2014) 150-158. doi:10.1016/j.freeradbiomed.2013.10.812.

[29] K. Abbas, M. Hardy, F. Poulhes, H. Karoui, P. Tordo, O. Ouari, F. Peyrot, Detection of superoxide production in stimulated and unstimulated living cells using new cyclic nitrone spin traps, Free Radic. Biol. Med. 71 (2014) 281-290. doi:10.1916/j.freeradbiomed.2014.03.019.

[30] K. Anzai, T. Aikawa, Y. Furukawa, Y. Matsushima, S. Urano, T. Ozawa, ESR measurement of rapid penetration of DMPO and DEPMPO spin traps through lipid bilayer membranes, Arch. Biochem. Biophys. 415 (2003) 251-256. doi:10.1016/S0003-9861(03)00260-1.

[31] A. Keszler, B. Kalyanaraman, N. Hogg, Comparative investigation of superoxide trapping by cyclic nitrone spin traps: the use of singular value decomposition and multiple linear regression analysis, Free Radic. Biol. Med. 35 (2003) 1149-1157.

[32] R. Lauricella, A. Allouch, V. Roubaud, J.-C. Bouteiller, B. Tuccio, A new kinetic approach to the evaluation of rate constants for the spin trapping of superoxide/hydroperoxyl radical by nitrones in aqueous media, Org. Biomol. Chem. 2 (2004) 1304-1309. doi:10.1039/B401333F.

[33] F.A. Villamena, S. Xia, J.K. Merle, R. Lauricella, B. Tuccio, C.M. Hadad, J.L. Zweier, Reactivity of superoxide radical anion with cyclic nitrones: role of intramolecular H-bond and electrostatic effects, J. Am. Chem. Soc. 129 (2007) 8177-8191. doi:10.1021/ja0702622.

[34] Y. Han, B. Tuccio, R. Lauricella, F.A. Villamena, Improved spin trapping properties by beta-cyclodextrin-cyclic nitrone conjugate, J. Org. Chem. 73 (2008) 7108-7117. doi:10.1021/jo8007176.

[35] O. Ouari, M. Hardy, H. Karoui, P. Tordo, Recent developments and applications of the coupled EPR/spin trapping technique (EPR/ST), in: Electron Paramagn. Reson., Gilbert, B. C.; Murphy, D. M.; Chechik, V. (Eds.), RSC Publishing, Cambridge, 2011: pp. 1-40.10.1039/9781849730877-00001. 
[36] K. Saito, M. Takahashi, M. Kamibayashi, T. Ozawa, M. Kohno, Comparison of superoxide detection abilities of newly developed spin traps in the living cells, Free Radic. Res. 43 (2009) 668-676. doi:10.1080/10715760902988850.

[37] N. Khan, C.M. Wilmot, G.M. Rosen, E. Demidenko, J. Sun, J. Joseph, J. O’Hara, B. Kalyanaraman, H.M. Swartz, Spin traps: in vitro toxicity and stability of radical adducts, Free Radic. Biol. Med. 34 (2003) 1473-1481. doi:10.1016/S08915849(03)00182-5.

[38] N. Rohr-Udilova, K. Stolze, B. Marian, H. Nohl, Cytotoxicity of novel derivatives of the spin trap EMPO, Bioorg. Med. Chem. Lett. 16 (2006) 541-546. doi:10.1016/j.bmcl.2005.10.060.

[39] V. Roubaud, S. Sankarapandi, P. Kuppusamy, P. Tordo, J.L. Zweier, Quantitative measurement of superoxide generation and oxygen consumption from leukocytes using electron paramagnetic resonance spectroscopy, Anal. Biochem. 257 (1998) 210-217. doi:10.1006/abio.1997.2542.

[40] H. Shi, G. Timmins, M. Monske, A. Burdick, B. Kalyanaraman, Y. Liu, J.-L. Clément, S. Burchiel, K.J. Liu, Evaluation of spin trapping agents and trapping conditions for detection of cell-generated reactive oxygen species, Arch. Biochem. Biophys. 437 (2005) 59-68. doi:10.1016/j.abb.2005.02.028.

[41] A. Samuni, C.M. Krishna, P. Riesz, E. Finkelstein, A. Russo, Superoxide reaction with nitroxide spin-adducts, Free Radic. Biol. Med. 6 (1989) 141-148. doi:10.1016/0891-5849(89)90111-1.

[42] L.A. Reinke, D.R. Moore, P.B. McCay, Degradation of DMPO adducts from hydroxyl and 1-hydroxyethyl radicals by rat liver microsomes, Free Radic. Res. 25 (1996) 467-474. doi:10.3109/10715769609149069.

[43] G.M. Rosen, B.A. Freeman, Detection of superoxide generated by endothelial cells, Proc. Natl. Acad. Sci. 81 (1984) 7269-7273.

[44] V. Khramtsov, L.J. Berliner, T.L. Clanton, NMR spin trapping: Detection of free radical reactions using a phosphorus-containing nitrone spin trap, Magn. Reson. Med. 42 (1999) 228-234. doi:10.1002/(SICI)1522-2594(199908)42:2<228::AIDMRM3>3.0.CO;2-T.

[45] H. Zhao, Detection and characterization of the product of hydroethidine and intracellular superoxide by HPLC and limitations of fluorescence, Proc. Natl. Acad. Sci. 102 (2005) 5727-5732. doi:10.1073/pnas.0501719102.

[46] N. Bézière, Y. Frapart, A. Rockenbauer, J.-L. Boucher, D. Mansuy, F. Peyrot, Metabolic stability of superoxide and hydroxyl radical adducts of a cyclic nitrone toward rat liver microsomes and cytosol: A stopped-flow ESR spectroscopy study, Free Radic. Biol. Med. 49 (2010) 437-446. doi:10.1016/j.freeradbiomed.2010.04.035.

[47] P. Wardman, Fluorescent and luminescent probes for measurement of oxidative and nitrosative species in cells and tissues: progress, pitfalls, and prospects, Free Radic. Biol. Med. 43 (2007) 995-1022. doi:10.1016/j.freeradbiomed.2007.06.026.

[48] K. Debowska, D. Debski, M. Hardy, M. Jakubowska, B. Kalyanaraman, A. Marcinek, R. Michalski, B. Michalowski, O. Ouari, A. Sikora, R. Smulik, J. Zielonka, Toward selective detection of reactive oxygen and nitrogen species with the use of fluorogenic probes--Limitations, progress, and perspectives, Pharmacol. Rep. PR. 67 (2015) 756-764. doi:10.1016/j.pharep.2015.03.016.

[49] S.I. Dikalov, D.G. Harrison, Methods for detection of mitochondrial and cellular 
reactive oxygen species, Antioxid. Redox Signal. 20 (2014) 372-382. doi:10.1089/ars.2012.4886.

[50] E. Marchesi, C. Rota, Y.C. Fann, C.F. Chignell, R.P. Mason, Photoreduction of the fluorescent dye 2'-7' -dichlorofluorescein: A spin trapping and direct electron spin resonance study with implications for oxidative stress measurements, Free Radic. Biol. Med. 26 (1999) 148-161. doi:10.1016/S0891-5849(98)00174-9.

[51] M.G. Bonini, C. Rota, A. Tomasi, R.P. Mason, The oxidation of 2',7'dichlorofluorescin to reactive oxygen species: A self-fulfilling prophesy?, Free Radic. Biol. Med. 40 (2006) 968-975. doi:10.1016/j.freeradbiomed.2005.10.042.

[52] J.J. Hu, N.-K. Wong, S. Ye, X. Chen, M.-Y. Lu, A.Q. Zhao, Y. Guo, A.C.-H. Ma, A.Y.-H. Leung, J. Shen, D. Yang, Fluorescent Probe HKSOX-1 for Imaging and Detection of Endogenous Superoxide in Live Cells and In Vivo, J. Am. Chem. Soc. 137 (2015) 6837-6843. doi:10.1021/jacs.5b01881.

[53] J. Zielonka, M. Hardy, B. Kalyanaraman, HPLC study of oxidation products of hydroethidine in chemical and biological systems: ramifications in superoxide measurements, Free Radic. Biol. Med. 46 (2009) 329-338. doi:10.1016/j.freeradbiomed.2008.10.031.

[54] G.J. Maghzal, R. Stocker, Improved analysis of hydroethidine and 2hydroxyethidium by HPLC and electrochemical detection, Free Radic. Biol. Med. 43 (2007) 1095-1096. doi:10.1016/j.freeradbiomed.2007.06.023.

[55] J. Zielonka, B. Kalyanaraman, Hydroethidine- and MitoSoX-derived red fluorescence is not a reliable indicator of intracellular superoxide formation: another inconvenient truth, Free Radic. Biol. Med. 48 (2010) 983-1001. doi:10.1016/j.freeradbiomed.2010.01.028.

[56] S. Dikalov, M. Skatchkov, E. Bassenge, Spin trapping of superoxide radicals and peroxynitrite by 1-hydroxy-3-carboxy-pyrrolidine and 1-hydroxy-2,2,6,6tetramethyl-4-oxo-piperidine and the stability of corresponding nitroxyl radicals towards biological reductants, Biochem. Biophys. Res. Commun. 231 (1997) 701704. doi:10.1006/bbrc.1997.6174.

[57] S.I. Dikalov, W. Li, P. Mehranpour, S.S. Wang, A.M. Zafari, Production of extracellular superoxide by human lymphoblast cell lines: comparison of electron spin resonance techniques and cytochrome $\mathrm{C}$ reduction assay, Biochem. Pharmacol. 73 (2007) 972-980. doi:10.1016/j.bcp.2006.12.012.

[58] S.I. Dikalov, I.A. Kirilyuk, M. Voinov, I.A. Grigor'ev, EPR detection of cellular and mitochondrial superoxide using cyclic hydroxylamines, Free Radic. Res. 45 (2011) 417-430. doi:10.3109/10715762.2010.540242.

[59] G. Bačić, A. Pavićević, F. Peyrot, In vivo evaluation of different alterations of redox status by studying pharmacokinetics of nitroxides using magnetic resonance techniques, Redox Biol. 8 (2015) 226-242. doi:10.1016/j.redox.2015.10.007.

[60] C. Decroos, Y. Li, G. Bertho, Y. Frapart, D. Mansuy, J.-L. Boucher, Oxidation of tris(p-carboxyltetrathiaaryl)methyl radical EPR probes: evidence for their oxidative decarboxylation and molecular origin of their specific ability to react with $02^{*}$-, Chem. Commun. Camb. Engl. (2009) 1416-1418. doi:10.1039/b819259f.

[61] C. Decroos, Y. Li, G. Bertho, Y. Frapart, D. Mansuy, J.-L. Boucher, Oxidative and reductive metabolism of tris(p-carboxyltetrathiaaryl)methyl radicals by liver microsomes, Chem. Res. Toxicol. 22 (2009) 1342-1350. doi:10.1021/tx9001379.

[62] F. Leinisch, J. Jiang, E.F. DeRose, V.V. Khramtsov, R.P. Mason, Investigation of spin- 
trapping artifacts formed by the Forrester-Hepburn mechanism, Free Radic. Biol. Med. 65 (2013) 1497-1505. doi:10.1016/j.freeradbiomed.2013.07.006.

[63] L.W. Oberley, G.R. Buettner, The production of hydroxyl radical by bleomycin and iron (II), FEBS Lett. 97 (1979) 47-49. doi:10.1016/0014-5793(79)80049-6.

[64] S. Pietri, M. Culcasi, P.J. Cozzone, Real-time continuous-flow spin trapping of hydroxyl free radical in the ischemic and post-ischemic myocardium, Eur. J. Biochem. 186 (1989) 163-173. doi:10.1111/j.1432-1033.1989.tb15191.x.

[65] M.-A. Barbacanne, J.-P. Souchard, B. Darblade, J.-P. Iliou, F. Nepveu, B. Pipy, F. Bayard, J.-F. Arnal, Detection of superoxide anion released extracellularly by endothelial cells using cytochrome c reduction, ESR, fluorescence and lucigeninenhanced chemiluminescence techniques, Free Radic. Biol. Med. 29 (2000) 388396. doi:10.1016/S0891-5849(00)00336-1.

[66] S.K. Jackson, K.J. Liu, M. Liu, G.S. Timmins, Detection and removal of contaminating hydroxylamines from the spin trap DEPMPO, and re-evaluation of its use to indicate nitrone radical cation formation and $\mathrm{S}(\mathrm{N}) 1$ reactions, Free Radic. Biol. Med. 32 (2002) 228-232. doi:10.1016/S0891-5849(01)00795-X.

[67] A. Grzelak, B. Rychlik, G. Bartosz, Light-dependent generation of reactive oxygen species in cell culture media, Free Radic. Biol. Med. 30 (2001) 1418-1425. doi:10.1016/S0891-5849(01)00545-7.

[68] B. Halliwell, Oxidative stress in cell culture: an under-appreciated problem?, FEBS Lett. 540 (2003) 3-6. doi:10.1016/S0014-5793(03)00235-7.

[69] D.A. Hume, S. Gordon, P.J. Thornalley, J.V. Bannister, The production of oxygencentered radicals by bacillus-Calmette-Guerin-activated macrophages. An electron paramagnetic resonance study of the response to phorbol myristate acetate, Biochim. Biophys. Acta. 763 (1983) 245-250. doi:10.1016/0167-4889(83)901313.

[70] B.E. Britigan, G.M. Rosen, B.Y. Thompson, Y. Chai, M.S. Cohen, Stimulated human neutrophils limit iron-catalyzed hydroxyl radical formation as detected by spintrapping techniques., J. Biol. Chem. 261 (1986) 17026-17032.

[71] S. Pou, M.S. Cohen, B.E. Britigan, G.M. Rosen, Spin-trapping and human neutrophils. Limits of detection of hydroxyl radical, J. Biol. Chem. 264 (1989) 12299-12302.

[72] C.L. Ramos, S. Pou, B.E. Britigan, M.S. Cohen, G.M. Rosen, Spin trapping evidence for myeloperoxidase-dependent hydroxyl radical formation by human neutrophils and monocytes., J. Biol. Chem. 267 (1992) 8307-8312.

[73] C.M. Mansbach, G.M. Rosen, C.A. Rahn, K.E. Strauss, Detection of free radicals as a consequence of rat intestinal cellular drug metabolism, Biochim. Biophys. Acta. 888 (1986) 1-9. doi:10.1016/0167-4889(86)90063-7.

[74] J.L. Zweier, P. Kuppusamy, G.A. Lutty, Measurement of endothelial cell free radical generation: evidence for a central mechanism of free radical injury in postischemic tissues, Proc. Natl. Acad. Sci. U. S. A. 85 (1988) 4046-4050.

[75] J.L. Zweier, R. Broderick, P. Kuppusamy, S. Thompson-Gorman, G.A. Lutty, Determination of the mechanism of free radical generation in human aortic endothelial cells exposed to anoxia and reoxygenation, J. Biol. Chem. 269 (1994) $24156-24162$.

[76] D.J. Hassett, B.E. Britigan, T. Svendsen, G.M. Rosen, M.S. Cohen, Bacteria form intracellular free radicals in response to paraquat and streptonigrin. Demonstration of the potency of hydroxyl radical., J. Biol. Chem. 262 (1987) 
13404-13408.

[77] H.M. Swartz, Use of nitroxides to measure redox metabolism in cells and tissues, J. Chem. Soc. Faraday Trans. 1 Phys. Chem. Condens. Phases. 83 (1987) 191-202. doi:10.1039/F19878300191.

[78] G. Rosen, E. Rauckman, Formation and Reduction of a Nitroxide Radical by LiverMicrosomes, Biochem. Pharmacol. 26 (1977) 675-678. doi:10.1016/00062952(77)90049-1.

[79] B.C. Heng, H. Liu, Z. Ge, T. Cao, Mechanical dissociation of human embryonic stem cell colonies by manual scraping after collagenase treatment is much more detrimental to cellular viability than is trypsinization with gentle pipetting, Biotechnol. Appl. Biochem. 47 (2007) 33-37. doi:10.1042/BA20060151.

[80] P.L. McNeil, A method for incorporating macromolecules into adherent cells, J. Cell Biol. 98 (1984) 1556-1564. doi:10.1083/jcb.98.4.1556.

[81] U. Batista, M. Garvas, M. Nemec, M. Schara, P. Veranic, T. Koklic, Effects of different detachment procedures on viability, nitroxide reduction kinetics and plasma membrane heterogeneity of V-79 cells, Cell Biol. Int. 34 (2010) 663-668. doi:10.1042/CBI20090276.

[82] J.P. Revel, P. Hoch, D. Ho, Adhesion of culture cells to their substratum, Exp. Cell Res. 84 (1974) 207-218. doi:10.1016/0014-4827(74)90398-X.

[83] Y. Wu, J. Wu, D.Y. Lee, A. Yee, L. Cao, Y. Zhang, C. Kiani, B.B. Yang, Versican protects cells from oxidative stress-induced apoptosis, Matrix Biol. 24 (2005) 3-13. doi:10.1016/j.matbio.2004.11.007.

[84] K.T. Piercy, R.L. Donnell, S.S. Kirkpatrick, B.L. Mundy, S.L. Stevens, M.B. Freeman, M.H. Goldman, Effect of harvesting and sorting on $\beta-1$ integrin in canine microvascular cells, J. Surg. Res. 100 (2001) 211-216. doi:10.1006/jsre.2001.6247.

[85] M. Mutin, F. George, G. Lesaule, J. Sampol, Reevaluation of trypsin-EDTA for endothelial cell detachment before flow cytometry analysis, Endothelium. 4 (1996) 289-295. doi:10.3109/10623329609024704.

[86] H. Hirai, R. Umegaki, M. Kino-oka, M. Taya, Characterization of cellular motions through direct observation of individual cells at early stage in anchoragedependent culture, J. Biosci. Bioeng. 94 (2002) 351-356. doi:10.1016/S13891723(02)80176-1.

[87] N. Khan, O. Grinberg, C. Wilmot, H. Kiefer, H.M. Swartz, "Distant spin trapping": a method for expanding the availability of spin trapping measurements, J. Biochem. Biophys. Methods. 62 (2005) 125-130. doi:10.1016/j.jbbm.2004.10.001.

[88] E. Perrier, M.-P. Fournet-Bourguignon, E. Royere, S. Molez, H. Reure, L. Lesage, W. Gosgnach, Y. Frapart, J.-L. Boucher, N. Villeneuve, J.-P. Vilaine, Effect of uncoupling endothelial nitric oxide synthase on calcium homeostasis in aged porcine endothelial cells, Cardiovasc. Res. 82 (2009) 133-142. doi:10.1093/cvr/cvp034.

[89] R. Ameziane-El-Hassani, S. Morand, J.-L. Boucher, Y.-M. Frapart, D. Apostolou, D. Agnandji, S. Gnidehou, R. Ohayon, M.-S. Noël-Hudson, J. Francon, K. Lalaoui, A. Virion, C. Dupuy, Dual oxidase-2 has an intrinsic Ca2+-dependent H2O2-generating activity, J. Biol. Chem. 280 (2005) 30046-30054. doi:10.1074/jbc.M500516200.

[90] T. Tanigawa, Y. Kotake, L.A. Reinke, Spin trapping of superoxide from glass adherent polymorphonuclear leukocytes induced by N-formylmethionyl-leucylphenylalanine, Free Radic. Res. Commun. 19 (1993) 101-110. 
[91] B.E. Britigan, T.L. Roeder, D.M. Shasby, Insight into the nature and site of oxygencentered free radical generation by endothelial cell monolayers using a novel spin trapping technique, Blood. 79 (1992) 699-707.

[92] K. Abbas, M. Hardy, F. Poulhès, H. Karoui, P. Tordo, O. Ouari, F. Peyrot, Mediumthroughput ESR detection of superoxide production in undetached adherent cells using cyclic nitrone spin traps, Free Radic. Res. (2015) 1-7. doi:10.3109/10715762.2015.1045504.

[93] D.R. Duling, Simulation of multiple isotropic spin-trap EPR spectra, J. Magn. Reson. B. 104 (1994) 105-110. doi:10.1006/jmrb.1994.1062.

[94] A. Rockenbauer, L. Korecz, Automatic computer simulations of ESR spectra, Appl. Magn. Reson. 10 (1996) 29-43. doi:10.1007/BF03163097.

[95] S. Stoll, A. Schweiger, EasySpin, a comprehensive software package for spectral simulation and analysis in EPR, J. Magn. Reson. 178 (2006) 42-55. doi:10.1016/j.jmr.2005.08.013.

[96] E. Finkelstein, G.M. Rosen, E.J. Rauckman, Spin trapping of superoxide and hydroxyl radical: Practical aspects, Arch. Biochem. Biophys. 200 (1980) 1-16. doi:10.1016/0003-9861(80)90323-9.

[97] A. Samuni, A.J. Carmichael, A. Russo, J.B. Mitchell, P. Riesz, On the spin trapping and ESR detection of oxygen-derived radicals generated inside cells, Proc. Natl. Acad. Sci. 83 (1986) 7593-7597.

[98] K. Ranguelova, R.P. Mason, The fidelity of spin trapping with DMPO in biological systems, Magn. Reson. Chem. MRC. 49 (2011) 152-158. doi:10.1002/mrc.2709.

[99] G. Rosen, E. Rauckman, Spin trapping of the primary radical involved in the activation of the carcinogen N-hydroxy-2-acetylaminofluorene by cumene hydroperoxide-hematin, Mol. Pharmacol. 17 (1980) 233-238.

[100] H. Chandra, M. Symons, Hydration of spin-trap cations as a source of hydroxyl adducts, J. Chem. Soc.-Chem. Commun. (1986) 1301-1302. doi:10.1039/c39860001301.

[101] L. Eberson, Inverted spin trapping. Part III. Further studies on the chemical and photochemical oxidation of spin traps in the presence of nucleophiles, J. Chem. Soc. Perkin Trans. 2. (1994) 171-176. doi:10.1039/P29940000171.

[102] A.R. Forrester, S.P. Hepburn, Spin traps - Cautionary note, J. Chem. Soc. C-Org. (1971) 701-703. doi:10.1039/j39710000701.

[103] B. Tuccio, R. Lauricella, C. Frejaville, J. Bouteiller, P. Tordo, Decay of the hydroperoxyl spin adduct of 5-diethoxyphosphoryl-5-methyl-1-pyrroline N-oxide - an EPR kinetic-study, J. Chem. Soc.-Perkin Trans. 2. (1995) 295-298. doi:10.1039/p29950000295.

[104] D.I. Potapenko, T.L. Clanton, E.G. Bagryanskaya, N.P. Gritsan, V.A. Reznikov, V.V. Khramtsov, Nonradical mechanism of (bi)sulfite reaction with DEPMPO: cautionary note for S03*- radical spin trapping, Free Radic. Biol. Med. 34 (2003) 196-206. doi:10.1016/S0891-5849(02)01194-2.

[105] D.I. Potapenko, E.G. Bagryanskaya, Y.P. Tsentalovich, V.A. Reznikov, T.L. Clanton, V.V. Khramtsov, Reversible reactions of thiols and thiyl radicals with nitrone spin traps, J. Phys. Chem. B. 108 (2004) 9315-9324. doi:10.1021/jp049026t.

[106] G.S. Timmins, G.K. Barlow, J.A. Silvester, X.D. Wei, A.C. Whitwood, Use of isotopically labelled spin traps to determine definitely the presence or absence of 
non radical addition artefacts in EPR spin trapping systems, Redox Rep. 3 (1997) 125-133.

[107] F. Leinisch, K. Ranguelova, E.F. DeRose, J. Jiang, R.P. Mason, Evaluation of the Forrester-Hepburn mechanism as an artifact source in ESR spin-trapping, Chem. Res. Toxicol. 24 (2011) 2217-2226. doi:10.1021/tx2003323.

[108] M. Pignitter, A.C.F. Gorren, S. Nedeianu, K. Schmidt, B. Mayer, Inefficient spin trapping of superoxide in the presence of nitric-oxide: implications for studies on nitric-oxide synthase uncoupling, Free Radic. Biol. Med. 41 (2006) 455-463. doi:10.1016/j.freeradbiomed.2006.04.004.

[109] S.S. Eaton, G.R. Eaton, Rapid-scan EPR of nitroxide spin labels and semiquinones, Methods Enzymol. 563 (2015) 3-21. doi:10.1016/bs.mie.2015.06.027.

[110] D.G. Mitchell, G.M. Rosen, M. Tseitlin, B. Symmes, S.S. Eaton, G.R. Eaton, Use of rapid-scan EPR to improve detection sensitivity for spin-trapped radicals, Biophys. J. 105 (2013) 338-342. doi:10.1016/j.bpj.2013.06.005.

[111] J.R. Biller, M. Tseitlin, D.G. Mitchell, Z. Yu, L.A. Buchanan, H. Elajaili, G.M. Rosen, J.P.Y. Kao, S.S. Eaton, G.R. Eaton, Improved sensitivity for imaging spin trapped hydroxyl radical at $250 \mathrm{MHz}$, ChemPhysChem. 16 (2015) 528-531. doi:10.1002/cphc.201402835.

[112] H. Grasberger, S. Refetoff, Identification of the maturation factor for dual oxidase. Evolution of an eukaryotic operon equivalent, J. Biol. Chem. 281 (2006) 1826918272. doi:10.1074/jbc.C600095200. 


\section{Figure legends:}

Figure 1: Principle of spin trapping with DMPO. $\mathrm{R}^{\bullet}$ is a short-lived radical, such as $\mathrm{O}_{2}{ }^{\bullet-}$ or HO•.

Figure 2: Structure of cited spin traps. The seven-glucopyranose unit of the permethylated $\beta$-cyclodextrin in CD-DEPMPO and CD-DIPPMPO is shown as a cylinder and drawing is not to scale.

Figure 3: Proposed mechanisms for the disappearance of $\mathrm{O}_{2}{ }^{\bullet-}$ and $\mathrm{HO} \mathrm{C}^{\bullet}$ spin adducts of BMPO: A) in the presence of ferric hemeproteins ( $\mathrm{Hp}), \mathrm{B}$ ) in the presence of intracellular reductants. (Adapted from reference [46])

Figure 4: Procedure for sample preparation using RAW 264.7 macrophage suspensions in gas-permeable tubing as described by Abbas et al. [29].

Figure 5: Representative EPR spectra obtained by Abbas et al. [29] after 3-min incubation of BMPO (10 mM), DEPMPO (10 mM), or CD-DIPPMPO (5 mM) in the presence of PMAstimulated RAW 264.7 macrophages $\left(3.6 \pm 0.3 \times 10^{6}\right.$ cells $\left./ 100 \mu \mathrm{L}\right)$ in PBS (pH 7.1-7.4) and $1 \mathrm{mM}$ DTPA. The y-axis was expanded 5-fold for BMPO and 2-fold for DEPMPO for the sake of clarity. Only BMPO-OH is observed in the upper spectrum. The middle spectrum shows superimposition of DEPMPO-OOH ( $\star$ ) and DEPMPO-OH (๑). Only CD-DIPPMPO$\mathrm{OOH}$ is seen in the bottom spectrum. EPR parameters: microwave frequency, $9.85 \mathrm{GHz}$; microwave power, $10 \mathrm{~mW}$; modulation frequency, $100 \mathrm{kHz}$; modulation amplitude, 0.2 $\mathrm{mT}$; receiver gain, $60 \mathrm{~dB}$; time constant, $40.96 \mathrm{~ms}$; conversion time, $41.04 \mathrm{~ms}$; data points, 1024; sweep width, $15 \mathrm{mT}$; sweep time, $42.02 \mathrm{~s}$. Noise was filtered using the SVD method (see section 2.3).

Figure 6: Procedure for spin trapping experiments with HEK 293 cell lines, when EPR detection was performed on the supernatant. Stable human Nox5b-transfected HEK 293 cells (HEK-hNox5) and wild-type HEK 293 cells (HEK-WT) were cultured as previously described [89]. Human Duox2-transfected HEK 293 cells were transiently transfected with human Duox2 maturation factor (hDuoxA2) that allows expression of the mature enzyme at the plasma membrane [112]. The Duox2 cell lines transfected with the empty expression vector (pcDNA5FRT) were used as controls in this case. Cells ( $1 \times 10^{6}$ cells) in 6-well culture plates were washed with Hepes buffered Earle's solution (pH 7.2) and incubated for $30 \mathrm{~min}$ at $37^{\circ} \mathrm{C}$ in the same buffer containing EDTA, $\mathrm{CaCl}_{2}$, ionomycin, and BMPO. The $\mathrm{Ca}^{2+}$ dependence of the activity was evaluated with 30-min pre-incubations with BAPTA-AM (1,2-bis(2-aminophenoxy)ethane- $N, N, N^{\prime}, N^{\prime}$-tetraacetic acid tetrakis(acetoxymethyl ester), an intracellular calcium chelator), followed by incubations with the ionomycine-free mixture.

Figure 7: Representative EPR spectra obtained with BMPO on the supernatant of HEKhNox5 cells, HEK-hDuox2/hDuoxA2 cells, and respective control cells, or without cells, upon stimulation by ionomycin or after incubation with BAPTA-AM. 27 EPR spectra were sequential recorded over $18 \mathrm{~min}$, the sum of which is shown. Same EPR parameters as in Figure 5 except: microwave frequency, $9.82 \mathrm{GHz}$; microwave power, $5.1 \mathrm{~mW}$; sweep 
width, $6.6 \mathrm{mT}$. (Unpublished results)

Figure 8: Procedure for sample preparation with undetached RAW 264.7 macrophages on microscope coverslip glasses as described by Abbas et al. [92].

Figure 9: Flow chart for determining the origin of $\mathrm{HO}$ - adduct of cell-permeant spin traps such as DMPO, DEPMPO, or BMPO.

Figure 10: Different pathways leading to artifactual detection of nitroxides in biological systems. DMPO is used as a model spin trap in this figure but similar mechanisms exist for other cyclic nitrones. The EPR spectrum of 5,5-dimethyl-2-pyrrolidone- $N$-oxyl (DMPOX) is characterized by 7 lines and hyperfine coupling constants $A_{N}=0.72 \mathrm{mT}$ and $\mathrm{A}_{\mathrm{H} \gamma}=\mathrm{AH}_{\gamma^{\prime}}=0.41 \mathrm{mT}$ in water [99]. Nu: stands for nucleophiles such as $\mathrm{H}_{2} \mathrm{O}$, sulfite or thiols. 
Methods Accepted manuscript

Published in final edited form as:

Methods. 2016 May 6; 109: 31-43. doi: 10.1016/j.ymeth.2016.05.001

\section{Figures}

\section{Figure 1}

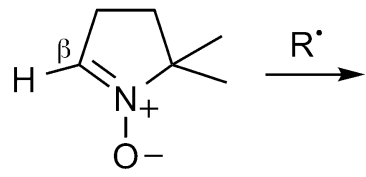

Spin trap

(EPR silent)

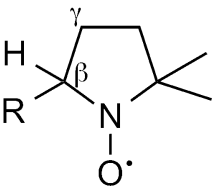

Spin adduct

(EPR visible) 


\section{Figure 2}<smiles>[X]C1(C)CCC=[N+]1[O-]</smiles>

DMPO:

EMPO:

BMPO:

AMPO:

DEPMPO:

DIPPMPO:<smiles>CC1(C)COP(=O)(OC2(C)CCC=[N+]2[O-])OC1</smiles>

CYPMPO

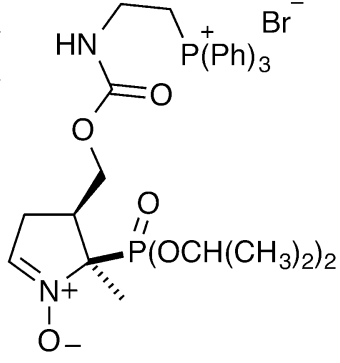

Mito-DIPPMPO

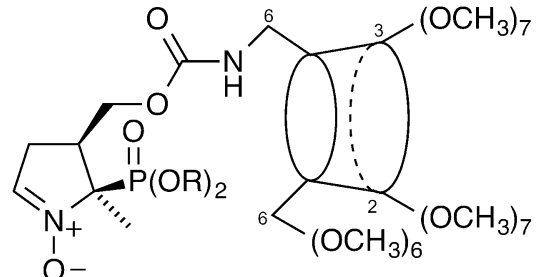

CD-DEPMPO: $\mathrm{R}=\mathrm{C}_{2} \mathrm{H}_{5}$ CD-DIPPMPO: $\mathrm{R}=\mathrm{CH}\left(\mathrm{CH}_{3}\right)_{2}$ 


\section{Figure 3}

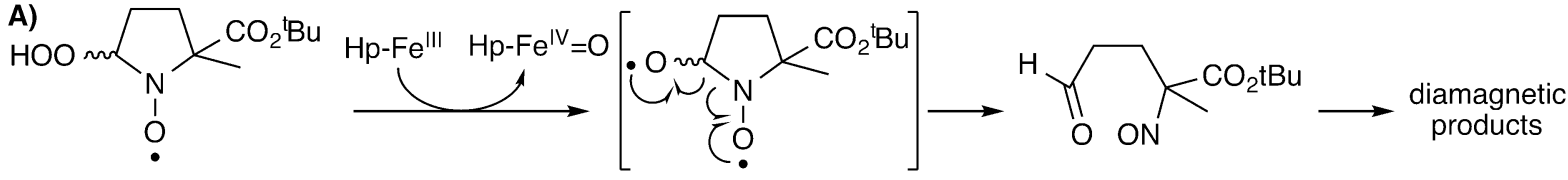

BMPO-OOH
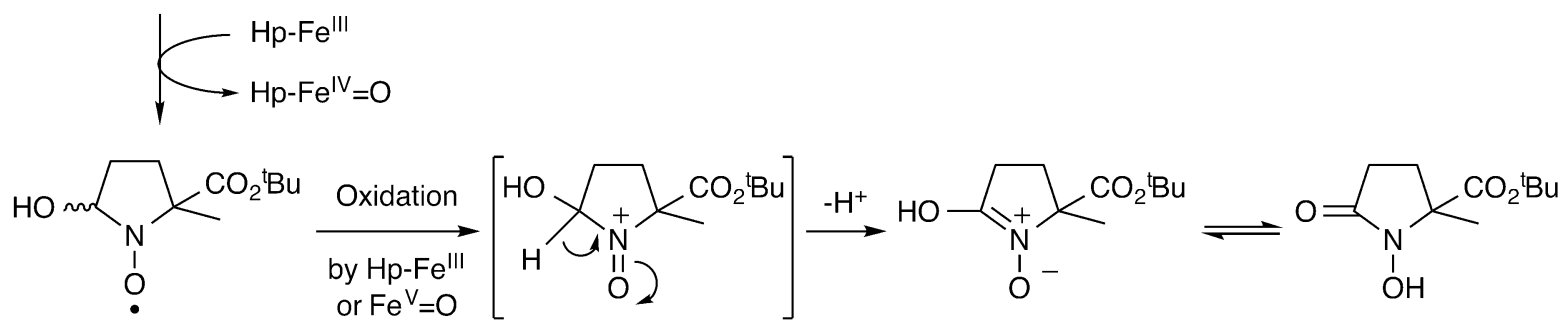

BMPO-OH

B)
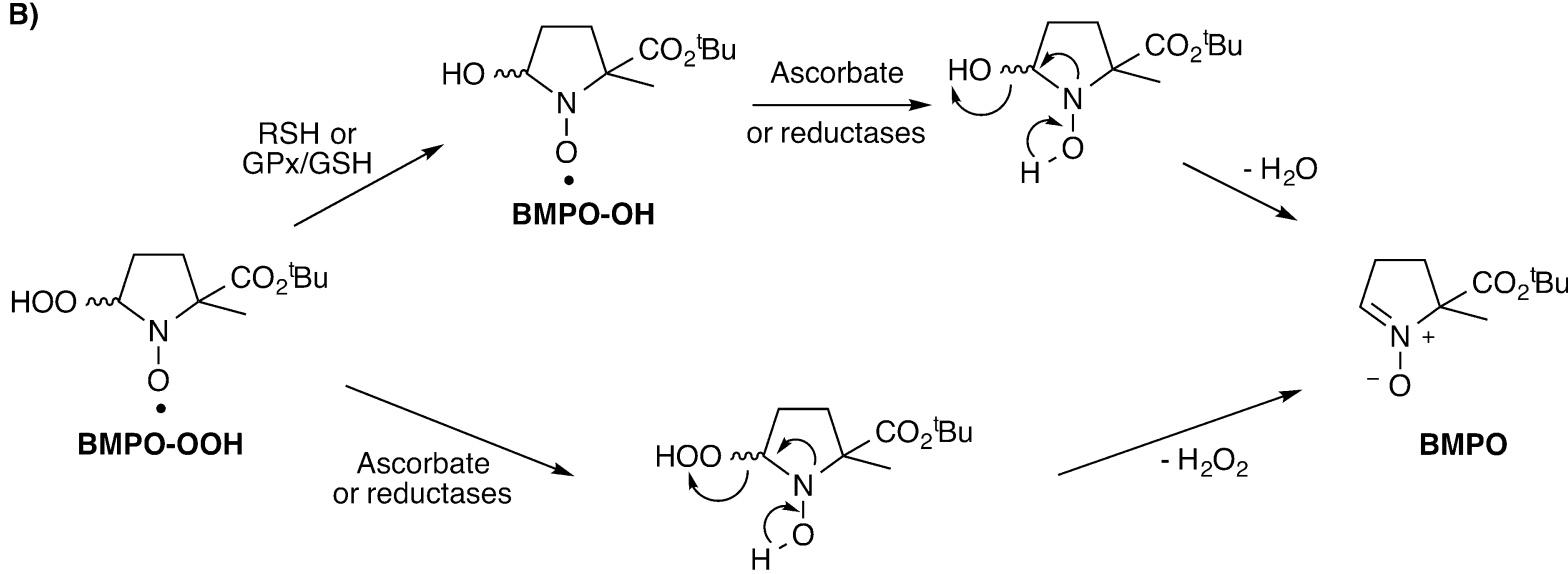


\section{Figure 4}

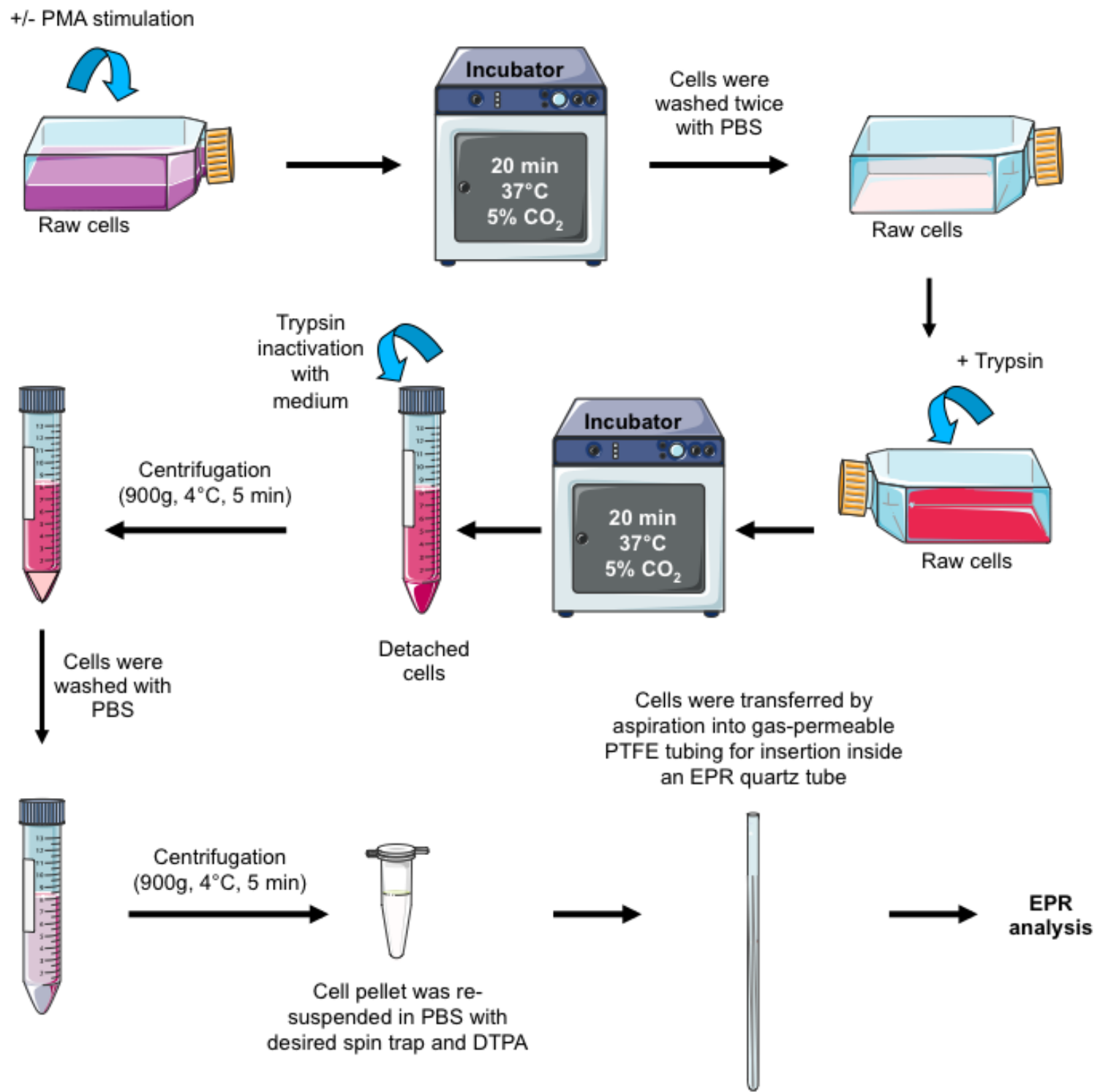




\section{Figure 5}
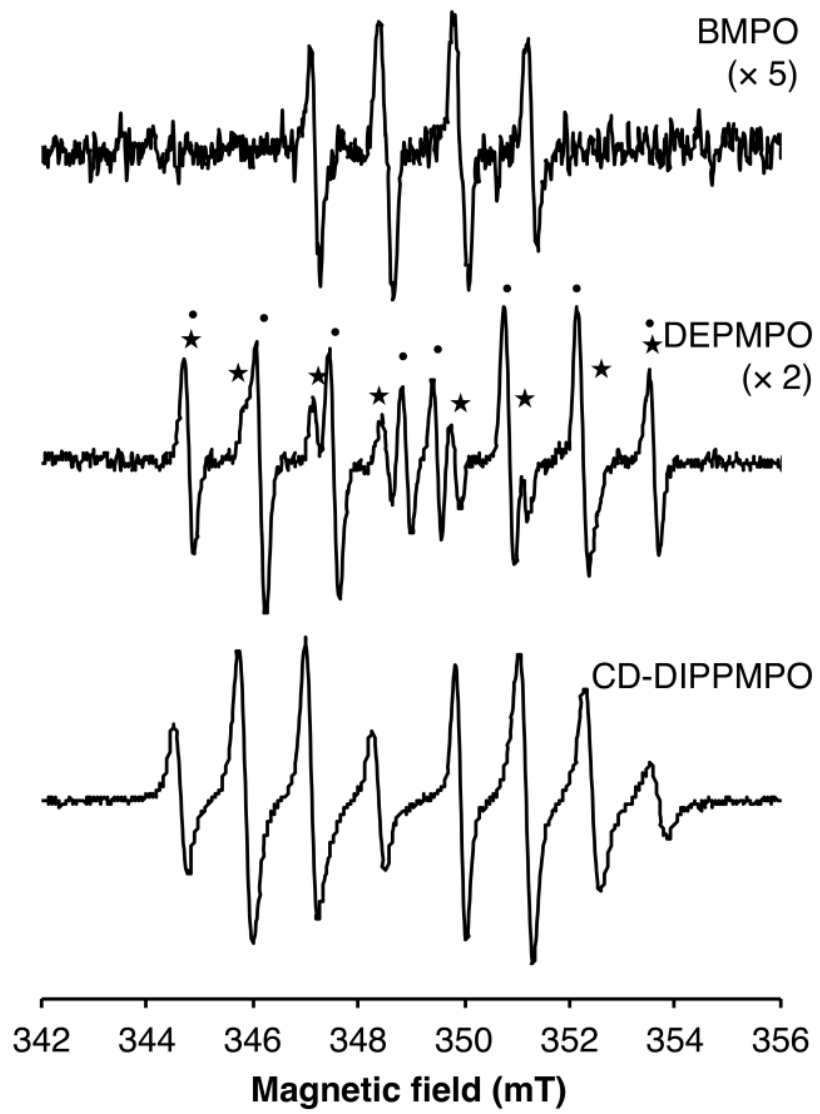


\section{Figure 6}

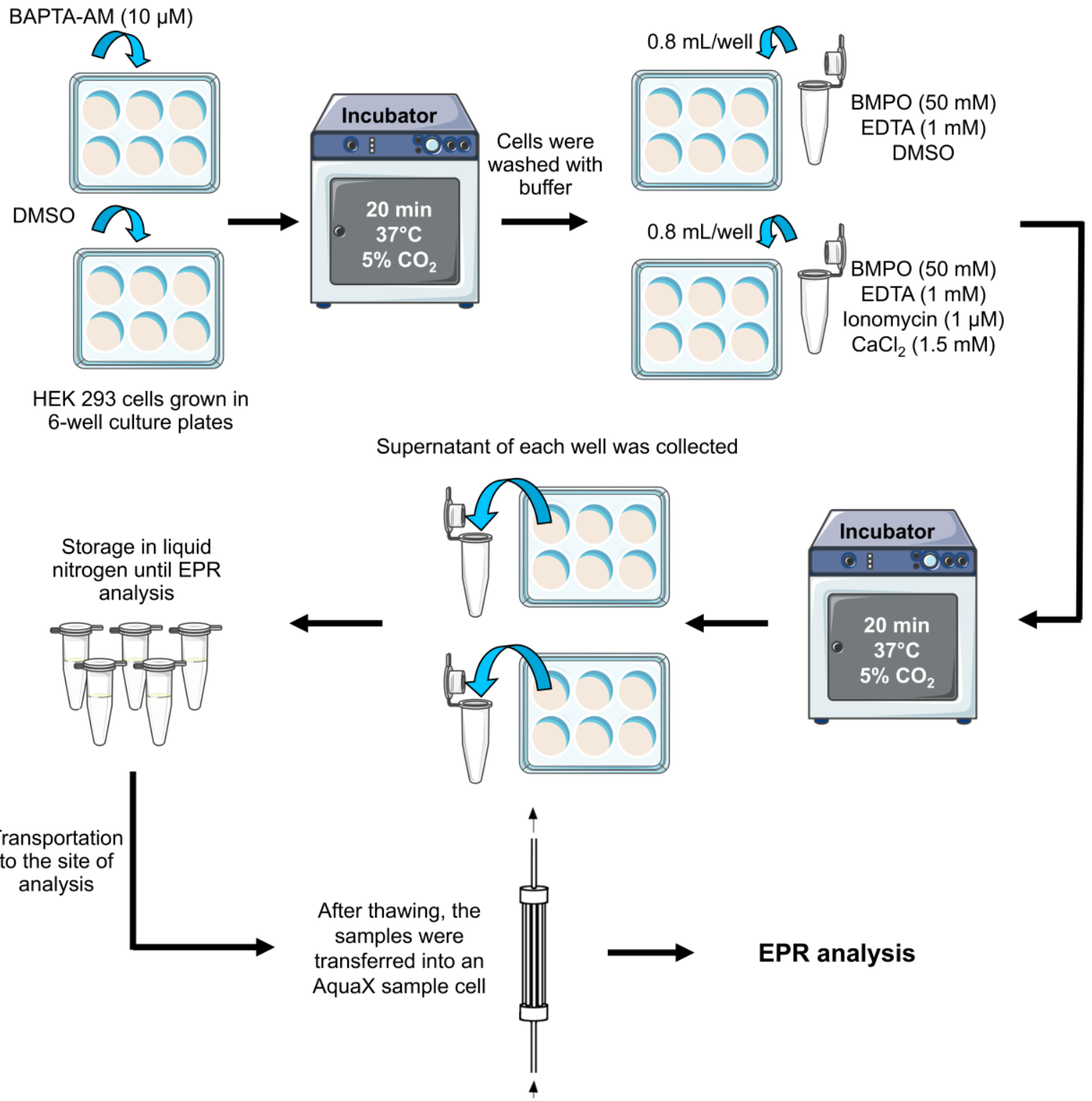




\section{Figure 7}

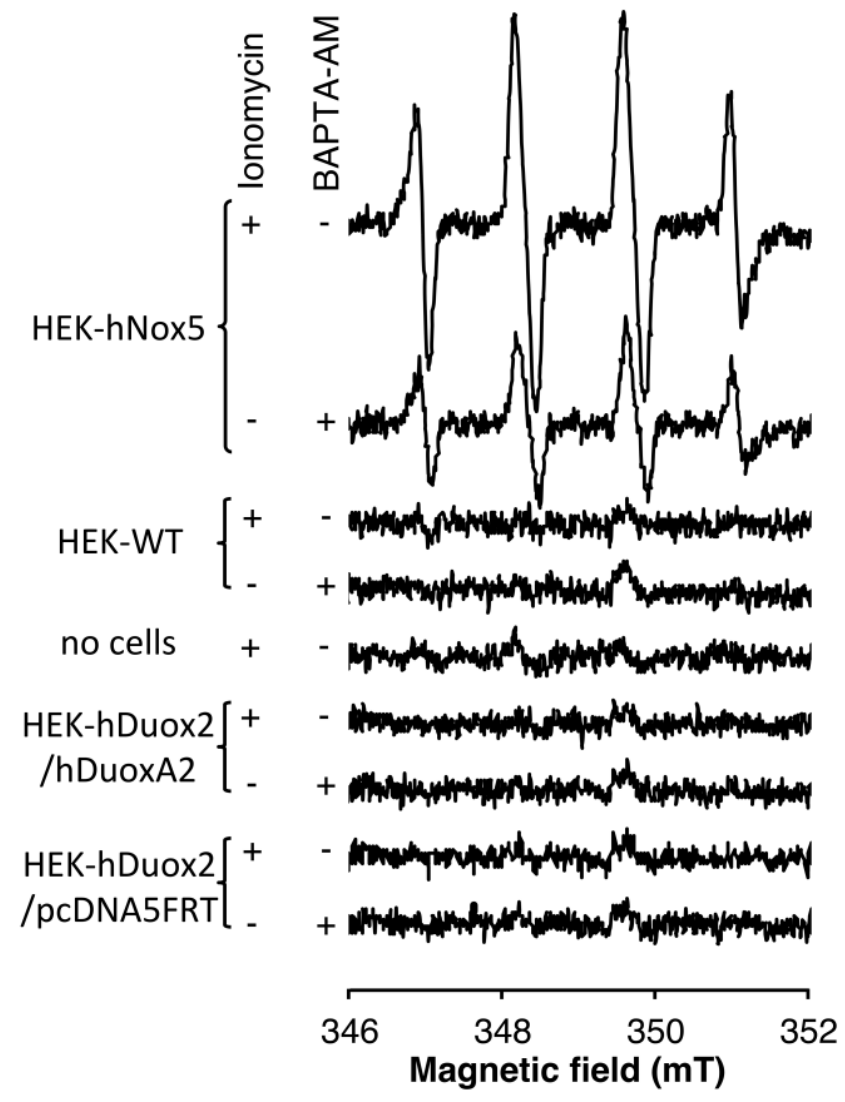




\section{Figure 8}
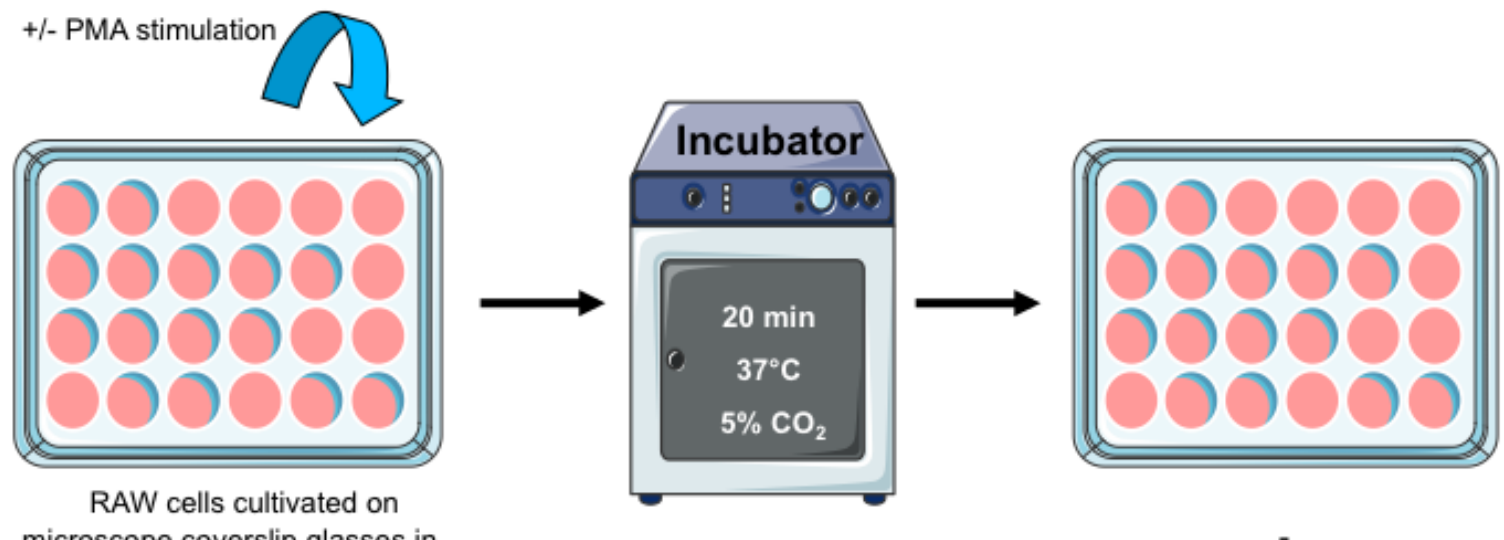

microscope coverslip glasses in

24-well culture plate
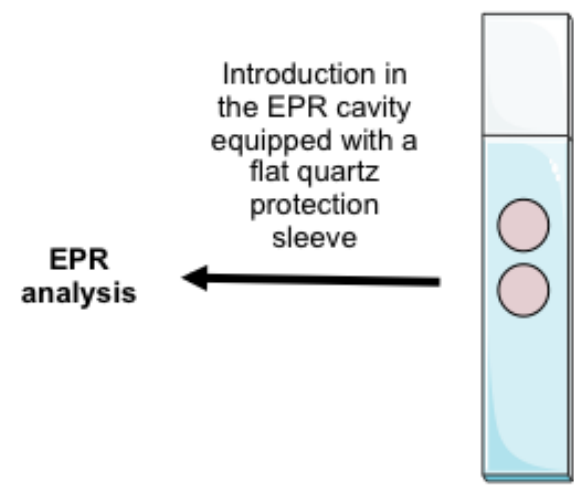

Microscope

coverslip

glasses were

fixed with

grease on a

quartz slide
Cells were washed twice with PBS

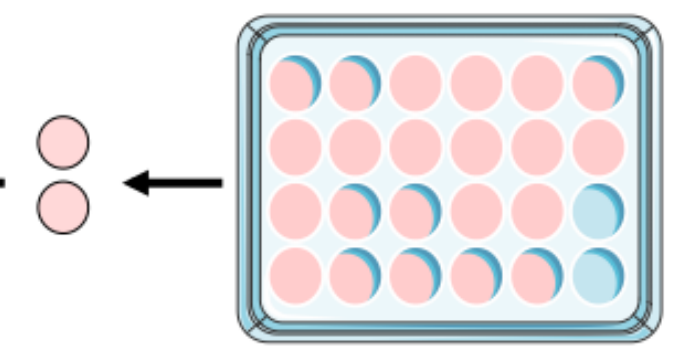

Cells were incubated for $20 \mathrm{~min}$ at $21^{\circ} \mathrm{C}$ with the desired spin trap $(5-10 \mathrm{mM})$ 


\section{Figure 9}

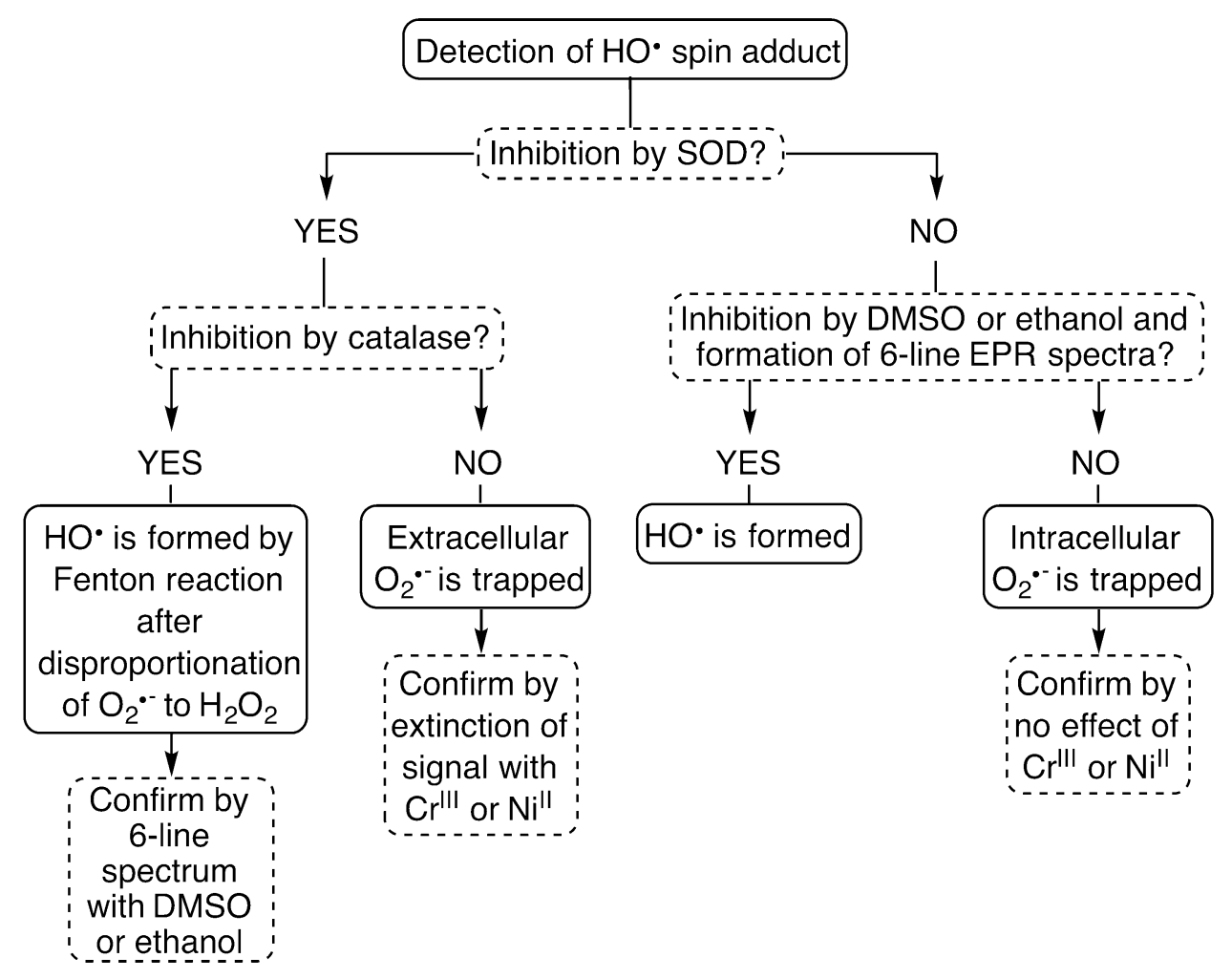




\section{Figure 10}

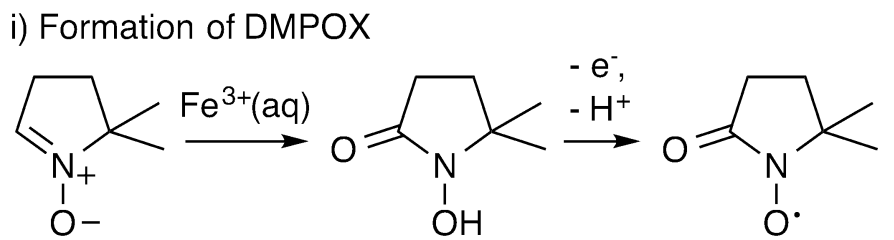

ii) Inverted spin trapping

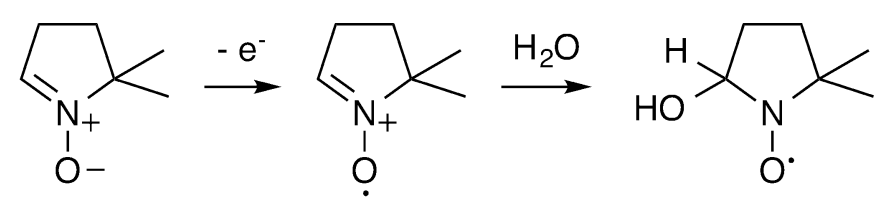

iii) Forrester-Hepburn mechanism

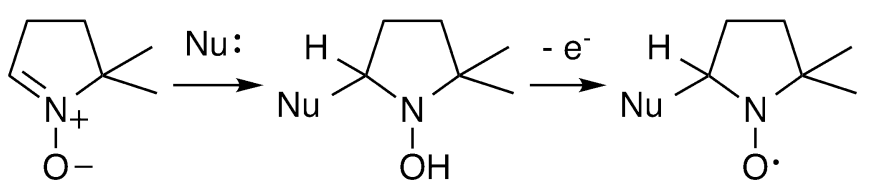

